\title{
Akarçay Kapalı Havzası için Hidrolojik Kuraklık Analizi
}

\section{Hydrological Drought Analysis for the Akarçay Closed Basin}

\author{
Mustafa Murat $\mathrm{KALE}^{1}$ (D) \\ ${ }^{1}$ Dr. Öğreim Üyesi, Çankırı Karatekin Üniversitesi, Edebiyat Fakültesi, Coğrafya Bölümü, Çankırı, Türkiye
}

ORCID: M.M.K. 0000-0001-6975-7069

\section{öz}

Kuraklık küresel ölçekte ekosistemin tüm bileşenlerinin karşı karşıya olduğu büyük bir problemdir. Hidrolojik kuraklık canlılığın devamlılığı için vazgeçilmez bir unsur olan su kaynaklarının tehlikeli bir şekilde azalmasına bağlı olarak gelişir. Meteorolojik kuraklığın yaygın bir şekilde gözlemlendiği Akarçay Kapalı Havzası önemli sulak alanlara ev sahipliği yapmaktadır. Son dönemlerde havza sulak alanları üzerindeki baskı iklim değişikliği, hatalı su kaynakları yönetim politikaları vb. nedenlere bağlı olarak artmıştır. Bu durum havza su bütçesinin bozulmasına ve sulak alanlarda alansal değişimlerin ortaya çıkmasına neden olmuştur. Bu çalışmada; Akarçay Kapalı Havzası'nda hidrolojik kuraklığa ait izlerin akarsu kuraklık indisi (SDI) kullanılarak ortaya çıkartılması hedeflenmiştir. Bu kapsamda kırk beş yıllık akım verilerinden oluşan zaman serileri kullanılarak dört farklı referans dönem için SDI indis değerleri hesaplanmıştır. SDI değerinin daha iyi yorumlanması için akım serileri üzerindeki olası eğilim Mann-Kendall testi ve Mann-Kendall sıra korelasyon test istatistiği ile araştırılmıştır. Çalışma sonuçlarına göre Akarçay Kapalı Havzası'nda seçili istasyonlarda hidrolojik kuraklığa ait izler tespit edilmiştir (SDI<0). Akım verilerinde, farklı referans dönemlerde farklı tarihlerde başlamak üzere anlamlı ve negatif yönlü eğilim belirlenmiştir. 1980'lerin ortasından itibaren hidrolojik kuraklığın genlik ve süresinin net bir şekilde arttığı tespit edilmiştir.

Anahtar kelimeler: Hidrolojik Kuraklık, Akarsu Akım, SDI

\section{ABSTRACT}

Drought is a major problem faced by the entire ecosystem on a global scale. Hydrological drought occurs because of the dangerous depletion of water resources, an indispensable aspect for the continuation of life. The Akarçay Closed Basin, where meteorological drought is commonly observed, is home to important wetlands. Recently, the pressure on the wetlands of this basin has increased because of climate change and poor water resource management policies, which has led to the deterioration of the basin water budget and spatial changes in the wetlands. This study examined the traces of hydrological drought in the Akarçay Closed Basin using the streamflow drought index (SDI). The SDI was calculated for four different reference periods using the time series consisting of 45 years of flow data. The possible trends on the flow series were investigated using the Mann-Kendall test and the Mann-Kendall rank correlation test statistics for a better interpretation of the SDI. Traces of hydrological drought were detected at selected stations in the Akarçay Closed Basin $(\mathrm{SDI}<0)$. A significant negative trend was found in the flow data starting on different dates during different reference periods. The magnitude and duration of hydrological drought have increased since the mid-1980s.

Keywords: Hydrological Drought, Stream Flow, SDI

Başvuru/Submitted: 06.03.2021 • Revizyon Talebi/Revision Requested: 22.04.2021 • Son Revizyon/Last Revision Received: 27.04 .2021 • Kabul/Accepted: 11.05 .2021

Sorumlu yazar/Corresponding author: Mustafa Murat KALE / mmuratkale@gmail.com

Atıf/Citation: Kale, M. M. (2021). Akarçay kapalı havzası için hidrolojik kuraklık analizi. Cografya Dergisi, 42, 165-180. https://doi.org/10.26650/JGEOG2021-892360 


\section{EXTENDED ABSTRACT}

Water resources, which are of vital importance for all elements of the ecosystem, have been under considerable pressure since the beginning of the last century (Shiklomanov, 1991; Arnell, 1999; Abbott, 2019). The natural water cycle system has been disrupted by many factors, such as the destruction and alteration of natural drainage systems, misuse of water resources, and human intervention in the climate system and water structures (dam, reservoir, and regulators) (Oki and Kanae, 2006). The cycle system is closely associated with many climatological and hydrological variables, and the interventions in these system elements have different effects in different geographies. Drought is the most frequently encountered problem, particularly in the current period (Huntington, 2006; Türkeş, 2010; Loon et al., 2016; Vazifehkhah ve Kahya, 2018; Dabanli, 2018; Katipoğlu, Acar and Şengül, 2020).

The concept of drought, which occurs depending on the severity, duration, and geographical distribution, is most generally defined as a water deficit that occurs when the natural water availability used by different systems in the world falls below its long-term average or normal on a regional scale for a particular time (Türkeş, 2012). Changes in precipitation and temperature play key roles in drought, which can be classified as a meteorological, agricultural, and hydrological drought in a particular geography. Underground and surface water resources, which are sensitive to changes in rainfall depth, face a descending trend in water income depending on the severity and duration of meteorological drought. Hydrological drought occurs because of long-term and negative precipitation trends. This type of drought is a dynamic process that occurs after meteorological drought and is dependent on the meteorological drought components. Hydrological drought affects all water-sensitive members of the ecosystem at different levels and is a phenomenon that directly threatens life.

This study examined the traces of hydrological drought in the Akarçay Closed Basin using the selected method. In this context, the streamflow drought indices (SDI) were calculated for different reference periods using the hydrometric time series of the selected stations. The possible trends in the hydrometric time series were investigated and evaluated together with the SDI to obtain a better interpretation of the SDI. Although the hydrometric time series were normalized to different transformations owing to their ease of application, significant results may not be obtained always. Therefore, nonparametric methods are often preferred in stochastic processes performed on hydrometric datasets. Nonparametric statistical methods, in which the assumptions of normality, independence, and homogeneity are not required, were preferred because of the results obtained in the study and the characteristics of the hydrometric data. The Mann-Kendall (M-K) test and M-K rank correlation test were the nonparametric methods preferred in this study.

The traces of hydrological drought in the Akarçay Closed Basin were investigated using SDI values and evaluated together with the possible trends. The results of this study can be divided into two main groups.

(i) The traces of hydrological drought were detected during 1966-2011 at the selected stations in the Akarçay Closed Basin. The SDI values met the conditions $\mathrm{SDI}<0$, and the negative trend obtained via trend analysis support this result.

(ii) The turning point of hydrological drought for the selected stations in the Akarçay Closed Basin was the mid-1980s. Since then, the magnitude and duration of hydrological drought have increased at all stations. This result is supported by the starting dates and significant negative trends recorded at the stations.

The Akarçay Closed Basin has gone through hydrological drought periods with an increased magnitude and duration. Hence, the severity of hydrological drought is expected to increase in the future due to climate change. In this context, the stakeholders in basin water resource management need to consider the hydrological droughts experienced in the past. Overall, the problem of access to water, which increases with increasing duration of the dry periods, is a common problem of the entire ecosystem. In this context, decision makers should immediately withdraw from activities that will disrupt the natural structure of basin's water resources. 


\section{GÍRIŞ}

Ekosistemin tüm öğeleri için hayati derecede önem taşıyan su kaynakları, geçtiğimiz yüzyılın başından itibaren daha önce karşılaşmadığı bir baskı altına girmiştir (Shiklomanov, 1991; Arnell, 1999; Abbott, 2019). Doğal drenaj sistemlerinin tahrip edilmesi ve/veya değiştirilmesi, su kaynaklarının hatalı kullanımı, iklim sistemine insanoğlu tarafindan yapılan müdahale ve su yapıları (baraj, rezervuar, regülatör vb.) gibi birçok etmene bağlı olarak doğal su çevrim sistemi bozulmaktadır (Oki ve Kanae; 2006). Doğal su çevrim sistemi (hidrolojik döngü), klimatolojik ve hidrolojik birçok değişken ile yakından ilişkili olup, sistem öğelerine yapılan müdahale farklı coğrafyalarda farklı şekillerde etkisini göstermektedir. Söz konusu etkiler arasında yer alan kuraklık, özellikle içinde bulunduğumuz dönemde gerek küresel ölçekte (Huntington, 2006; Loon vd., 2016) gerekse Türkiye ölçeğinde sıklıkla karş1 karşıya kalınan problemlerin başında gelmektedir (Türkeş, 2010; Vazifehkhah ve Kahya, 2018; Dabanli, 2018; Katipoğlu, Acar ve Şengül, 2020).

Şiddet, süre ve coğrafi dağılım bileşenlerine bağlı olarak gelişen kuraklık kavramı en genel hali ile yerkürede farklı sistemlerce kullanılan doğal su varlığının, belirli bir zaman süresince bölgesel ölçekte uzun süreli ortalamasının ya da normalinin altına düşmesi ile oluşan su açığı şeklinde tanımlanmaktadır (Türkeş, 2012). Meteorolojik, tarımsal ve hidrolojik kuraklık biçimlerinde sınıflara ayrılabilen kuraklığın belirli bir coğrafyada ortaya çıkmasında yağış ve sıcaklık değerlerinde meydana gelen değişimler anahtar bir rol üstlenir. Yağış miktarındaki değişime doğrudan duyarlı olan yeraltı ve yerüstü su kaynakları, meteorolojik kuraklığın şiddetine ve süresine bağlı olarak su gelirlerinde azalma eğilimi ile karşı karşıya kalmaktadır. Hidrolojik kuraklık; meteorolojik kuraklıktan daha sonra ortaya çıkan ve meteorolojik kuraklık bileşenlerine bağımlı olan dinamik bir sürece sahiptir. Hidrolojik kuraklığın gerçekleşmesi suya duyarlı olan tüm ekosistem üyelerini faklı düzeylerde etkilemekte ve doğrudan canlılığı tehdit eden bir olgu olarak karşımıza çıkmaktadır.

Hidrolojik kuraklık, küresel ölçekte etkilerini hissettiren iklim sistemindeki değişiklik sorunsalı ile yakından ilişkilidir. Ortalama sıcaklık değerinde kaydedilecek pozitif yönlü anomali ile birlikte yağış yüksekliğinde kaydedilecek negatif yönlü anomalinin süresi ve büyüklüğü hidrolojik kuraklığın üzerinde belirleyici bir role sahiptir. İklim değişikliği sorunsalının olası etkilerinin araştırıldığ 1 farklı modelleme çalışmalarının ortak sonucu sicaklık ve yağış parametrelerinde anomaliler gerçekleşeceği yönündedir (Dore, 2005; Trenberth, 2011; Şen vd., 2011; Önol, 2012). İklim değişikliğine bağlı olarak özellikle Anadolu coğrafyasında su havzalarının bütçelerinin değişmesi (Bozkurt ve Şen, 2013; Fujihara vd., 2008; Önol, Ünal ve Dalfes, 2009; Önol ve Semazzi, 2009) ve kurak - yarı kurak iklim bölgelerinde alansal büyüme yaşanması ve kurak yaz mevsimi sürelerinin artması (Erlat ve Türkeş, 2013; Önol vd., 2009; Türkeş, 1998) öngörülmektedir. Anadolu coğrafyasında 19752008 döneminde kaydedilen yağış değerlerinde Karadeniz sahil şeridi, kuzey doğu Anadolu ve Şile-Antalya aksı dışında kalan birçok bölgede anlamlı azalma eğilimi tespit edilmiştir (Çiçek ve Duman, 2015). İçinde bulunduğumuz dönemde Türkiye genelinde kurak geçen yılların sayısında anlamlı bir artış kaydedilmiştir (Akbaş, 2014). 1900 - 2005 döneminde Anadolu coğrafyasının doğal üyesi olduğu Akdeniz Havzası'nda anlamlı kuraklaşma eğilimleri tespit edilmiştir (Türkeş ve Erlat, 2003; Türkeş ve Tatlı, 2011). Bahsi geçen tüm öngörü ve bulguların su kaynaklarını etkileyeceği, önemli sulak alanlara sahip olan Anadolu coğrafyasında sulak alanlar üzerinde baskı oluşturacağı ve hidrolojik kuraklığı tetikleyeceği yadsınamaz bir gerçek olarak karşımıza çıkmaktadır. Bununla birlikte Anadolu coğrafyasında doğrudan hidrolojik kuraklığı ve izlerini araştıran çalışma sayısı oldukça sınırlıdır.

$\mathrm{Bu}$ çalışmaya konu olan Akarçay Kapalı Havzası Anadolu coğrafyasının önemli sulak alanlarını bünyesinde barındırmaktadır. Köppen-Geiger iklim sınıflandırmasına göre çok kurak iklimin (B) egemen olduğu havzada yarı kurak soğuk step alt iklimi (Bsk) baskın olarak görülür (Öztürk, Çetinkaya ve Aydın 2017). Akarçay Kapalı Havzası'nı çevreleyen yüksek dağlık kuşak ile göllere ev sahipliği yapan havza tabanı arasında 1000 m’ye ulaşan yükselti farkı bulunmaktadır. Bu durum iklimde yerel farklılıklar oluşturmakta ve havza genelinde karma iklim tipinin gerçekleşmesine neden olmaktadır (Tezcan vd., 2002; Bahadır, 2012). Havza tabanında yer alan Meteoroloji Genel Müdürlüğü’ne ait Afyonkarahisar merkez istasyonu uzun dönem rasat verilerine göre en soğuk ay ocak ayı $\left(0,3^{\circ} \mathrm{C}\right)$ iken en sıcak ay ise temmuz ayı $\left(22,1^{\circ} \mathrm{C}\right)$ 'dır. Yıllık toplam yağış miktarı 400 mm'nin biraz üzerinde olan havzada en fazla yağış ilkbahar ve kış mevsimlerinde yağmur ve kar yağışları şeklinde gerçekleşmektedir. Eber Gölü, Akşehir Gölü ve Karamık Sazlığı (Bataklığı)'na ev sahipliği yapan havza yaklaşık olarak 7400 $\mathrm{km}^{2}$ drenaj alanına sahiptir. Göçmen kuşların önemli uğrak alanları arasında olan Eber Gölü, Akşehir Gölü ve Karamık Sazlığ1 ulusal öneme haiz sulak alan statüsünde tescil edilmiştir. Akşehir Gölü'nün terminal göl statüsünde olduğu havzada, izlenen hatalı su kaynakları yönetim politikaları ve son dönemde etkisini arttıran iklim değişikliğinin tesiri altında havza su 
kaynakları büyük bir baskı altındadır (Bahadır, 2012; Dönmez, 2018). Bu bağlamda, havza tabanında yer alan Eber ve Akşehir göllerinde alansal değişiklikler gerçekleşmiş̧ir (Sener, Davraz ve Sener, 2010; Yıldırım, Erdoğan ve Uysal, 2011; Bahadır, 2013). 1990-2016 yılları arasında Eber Gölü'nde alansal olarak \%2,3 büyüme ve Akşehir Gölü’nde alansal olarak \%71,23 düzeyinde küçülme kaydedilmiştir (Köle, Ataol ve Erkal, 2016). Aynı dönemde Akşehir Gölü kıyı çizgisinin gölün kuzeybatı, kuzeydoğu, güneybatı ve güneydoğu akslarında sırasıyla 158,22 $\mathrm{m} / \mathrm{y} 11,317,45 \mathrm{~m} / \mathrm{y} 11,111,76 \mathrm{~m} / \mathrm{y}$ ll ve $156,60 \mathrm{~m} / \mathrm{y}$ ll düzeylerinde gerilediği tespit edilmiştir (Kale, 2018). Falkenmark su stres indisine göre kişi başına düşen su miktarı açısından Akarçay Kapalı Havzası su sıkıntısı eşik değerine yakındır (Aydın vd. 2017). 1901-2015 döneminde özellikle havzanın güney ve doğu aksında standartlaştırılmış yağış indisinde anlamlı değişiklikler tespit edilmiş ve artan bir eğilim ile meteorolojik kuraklık olduğu belirlenmiştir (Kuzay ve Tombul, 2020). Havza su kaynakları üzerindeki baskı her geçen gün şiddetini arttırmaktadır. Buna karşın Akarçay Kapalı Havzası özelinde gerçekleşmiş olan olası hidrolojik kuraklığın izlerini araştıran ve coğrafi bakış açısı ile yorumlayan bir çalışma bulunmamaktadır.

Bu çalışmada, Akarçay Kapalı Havzası'na ait akarsu akım verileri kullanılarak, havzadaki hidrolojik kuraklığın izlerinin araştırılması ve akarsu akımlarındaki olası eğilimlerin belirlenmesi hedeflenmiştir.

\section{MATERYAL VE YÖNTEM}

$\mathrm{Bu}$ çalışmanın amacı Akarçay Kapalı Havzası'ndaki hidrolojik kuraklığa ait izlerin akarsu kuraklık indis (SDI) değerleri aracılığıyla ortaya çıkartılmasıdır. Bu kapsamda seçili istasyonlara ait hidrometrik zaman serileri kullanılarak farklı referans periyotlar boyunca SDI değerleri hesaplanmıştır. SDI değerlerinin daha iyi yorumlanması için hidrometrik zaman serilerindeki olası eğilim araştırılmış ve SDI sonuçları ile bir arada değerlendirilmiş̧tir.

Çalışma genelinde kullanılan hidrometrik zaman serileri aylık ortalama akarsu akımlarından oluşmaktadır. Akım verileri; Devlet Su İşleri Genel Müdürlüğü (DSI) ve Elektrik İşleri Etüt İdaresi (EİE) tarafından işletilmiş olan akım gözlem istasyonlarına (AGI) aittir. Çalışma sahasında oldukça fazla sayıda AGİ bulunmasına karşın bu çalışmada sadece dört istasyona ait ölçüm kayıtları kullanılmıştır. Çalışmada kullanılan AGI'lerin seçiminde üç temel ölçüt dikkate alınmıştır. Bu kıstaslar; $(i)$ istasyondaki akım ölçümlerinin hidrometrik çalışmalardaki asgari süreyi temsil eden en az otuz yıllık bir dönemi kapsaması (Kahya ve Kalaycı,
2004), (ii) istasyondaki akım verilerinin kesintisiz veya en az kesintiye sahip olması ile (iii) antropojenik etkiden en az düzeyde etkilenecek konumda olmasıdır. Antropojenik etkinin akarsu akımları üzerindeki etkisinin azaltılması için AGİ konumlarının baraj gövdelerinin membasında olmasına dikkat edilmiştir. AGI'nin baraj dışında, farklı amaçlarla inşa edilmiş gölet ve benzeri yapıların mansabında olması durumunda; gölet öncesi ve sonrası dönemlere ait akım verileri karşılaştırılarak bir sıçrama olup olmadığı araştırılmıştır. Sıçrama olmaması durumunda AGİ verilerinin kullanılmasına karar verilmiştir. İstasyonlara ait eksik veriler boyutsuz debi süreklilik çizgileri ile tahmin edilmiştir (Bayazıt ve Önöz, 2008). Çalışmada kullanılan seçili istasyonların konumları Şekil 1'de ve istasyonlara ait temel bilgiler Tablo 1'de verilmiştir. Çalışmada kullanılan istasyonlar, drenaj alanları ve konumları itibariyle Akarçay Kapalı Havzası içerisinde farklı alt havzaları temsil etmektedir. E11002 ve D11A013 numaralı istasyonlar Eber Gölü drenaj alanında yer alırken D11A002 ve D11A015 numaralı istasyonlar Akşehir Gölü drenaj alanında yer almaktadır.

Nalbantis ve Tsakiris (2009) tarafindan geliştirilen SDI, kümülatif akış hacimlerini kullanarak kuraklık başlangıcını ve süresini tahmin etmek için gerçek zamanlı akım ölçümlerinden türetilmiş olan bir indistir. Hidrolojik yıl içerisinde farklı dönemler boyunca hesaplanabilen indise ait kümülatif akış hacmi eşitlik 1 kullanılarak bulunur (Nalbantis ve Tsakiris, 2009).

$$
\mathrm{V}_{i, k}=\sum_{j=1}^{3 k} Q_{i, j} \quad i=1,2, \ldots \quad j=1,2, \ldots, 12 \quad k=1,2,3,4
$$

Eşitlikte, $i$; hidrolojik yılı, $j$; hidrolojik yıla ait ayı, $Q_{i, j}$ akımı, $k$; referans dönemi $V_{i, k}$, ise $k$ referans dönem için kümülatif akış hacmini ifade etmektedir. Referans dönem hidrolojik yılı dört farklı aralıkta inceleyebilmektedir. Referans dönem bir değerini aldığında ekim - aralık ayları arası $(k=1)$; referans dönem iki değerini aldığında ekim - mart ayları arası $(k=2)$; referans dönem üç değerini aldığında ekim - haziran ayları arası $(k=3)$ ve referans dönem dört değerini aldığında tüm su yılı $(k=4)$ için kümülatif akış hacmi hesaplanır.

Kümülatif akış hacminin bulunmasından itibaren, SDI değeri eşitlik 2 yardımı ile bulunur (Nalbantis ve Tsakiris, 2009).

$$
S D I_{i, k}=\frac{V_{i, k}-\bar{V}_{k}}{S_{k}} \quad i=1,2, \ldots \quad k=1,2,3,4
$$

Burada, $\bar{V}_{k}$; referans periyoda ait kümülatif akarsu akımlarının ortalamasını, $S_{k}$; referans periyoda ait kümülatif akarsu akımlarının standart sapmasını $S D I_{i, k}$ ise referans periyod içerisinde yer alan hidrolojik aya ait akarsu kuraklık indisini ifade etmektedir (Nalbantis ve Tsakiris, 2009). 


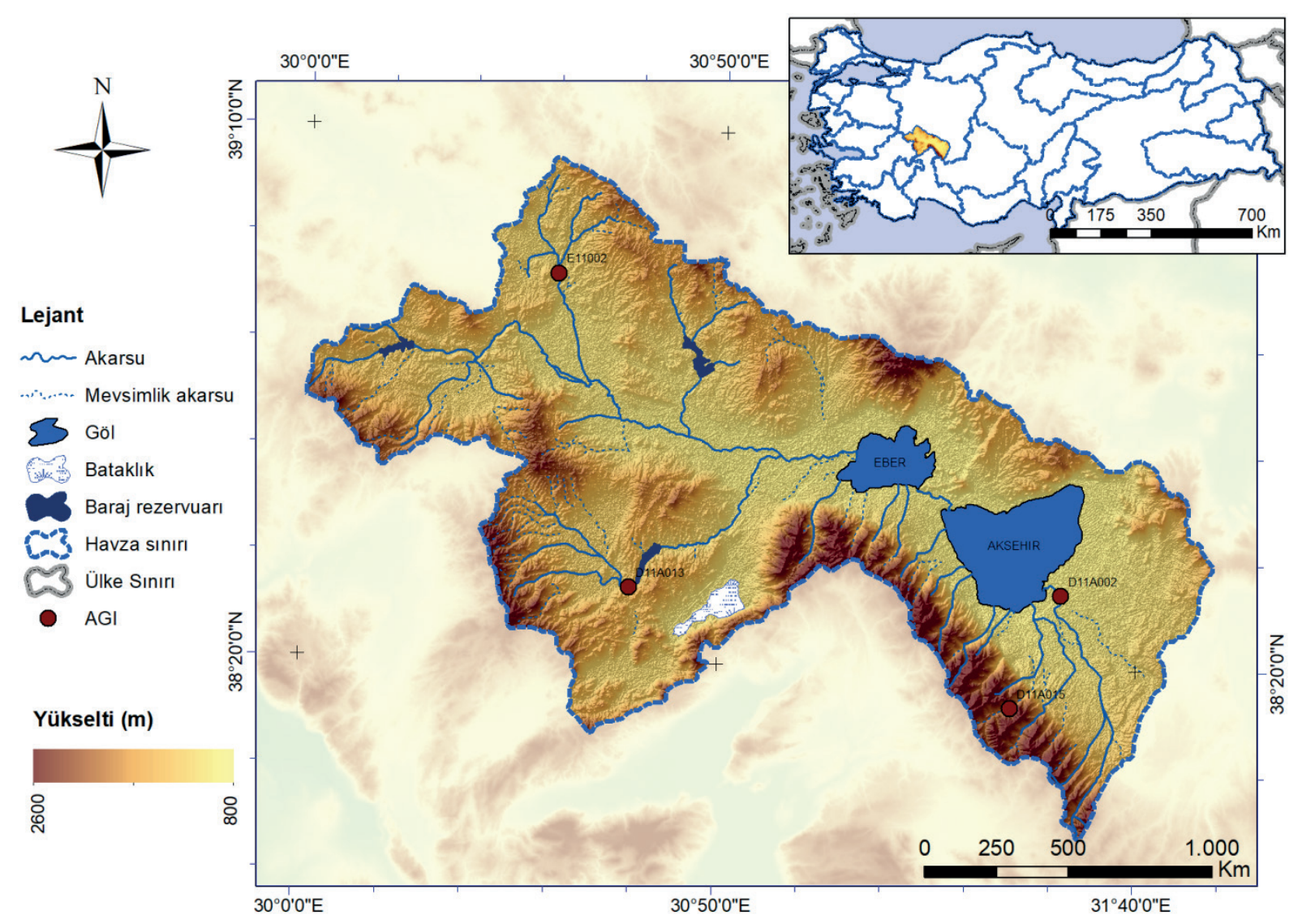

Şekil 1: Çalışma sahasına ait konum haritası.

Figure 1: The location map of the study area.

Tablo 1: Çalışmada kullanılan akım gözlem istasyonlarına ait genel bilgiler. Table 1: General information of river-gauging stations.

\begin{tabular}{|c|c|c|c|c|c|c|c|c|c|}
\hline \multirow{2}{*}{ Ad } & \multirow{2}{*}{ Yer } & \multirow{2}{*}{ Numara } & \multicolumn{2}{|c|}{ Koordinatlar } & \multirow{2}{*}{ Yükseklik (m) } & \multirow{2}{*}{ Drenaj alanı $\left(\mathbf{k m}^{2}\right)$} & \multicolumn{2}{|c|}{ Zaman serisi } & \multirow{2}{*}{ Süre (yıl) } \\
\hline & & & Enlem (K) & Boylam (D) & & & Başlangıç tarihi & Bitiş tarihi & \\
\hline Gazlıgöl & Sivrikaya Deresi & E11002 & $38^{\circ} 56^{\prime} 09^{\prime \prime}$ & $30^{\circ} 30^{\prime} 07^{\prime \prime}$ & 1049 & 360,80 & 1966 & 2011 & 45 \\
\hline Ortaköy & Adıyan Çayı & D11A002 & $38^{\circ} 26^{\prime} 50^{\prime \prime}$ & $31^{\circ} 30^{\prime} 57^{\prime \prime}$ & 965 & 631,90 & 1966 & 2011 & 45 \\
\hline Selevir Barajı Girişi & Kali Çayı & D11A013 & $38^{\circ} 26^{\prime} 56^{\prime \prime}$ & $30^{\circ} 38^{\prime} 47^{\prime \prime}$ & 1110 & 690,00 & 1966 & 2011 & 45 \\
\hline Cankurtran & Engilli Dere & D11A015 & $38^{\circ} 16^{\prime} 27^{\prime \prime}$ & $31^{\circ} 25^{\prime} 13^{\prime \prime}$ & 1502 & 46,80 & 1966 & 2011 & 45 \\
\hline
\end{tabular}

SDI değerleri dikkate alınarak hidrolojik kuraklık beş sınıfa ayrilır (Nalbantis 2008; Nalbantis ve Tsakiris, 2009). Sınıflandırma aralıkları Tablo 2'de verildiği gibidir. Bu çalışmada dört farklı referans dönem $(k=1,2,3,4)$ için istasyon

Tablo 2: SDI indisine göre hidrolojik kuraklık sınıfları (Nalbantis ve Tsakiris 2009).

Table 2: Description of streamflow drought classes based on SDI.

\begin{tabular}{ccc}
\hline Sınıf & Kriter & Tanım \\
\hline 0 & $\mathrm{SDI} \geq 0,0$ & Kuraklık yok \\
1 & $-1,0 \leq \mathrm{SDI}<0,0$ & Hafif kurak \\
2 & $-1,5 \leq \mathrm{SDI}<-1,0$ & Orta derece kurak \\
3 & $-2 \leq \mathrm{SDI}<-1.5$ & Şiddetli kurak \\
4 & $\mathrm{SDI} \leq-2,0$ & Aşırı kurak \\
\hline
\end{tabular}

bazlı olarak SDI değerleri hesaplanmıştır. Hesaplamalar sonucunda elde edilen negatif indis değerleri hidrolojik kurak dönemleri, pozitif indis değerleri ise hidrolojik kuraklığın olmadığı dönemleri ifade etmektedir.

Çalışmada SDI değerlerinin daha iyi yorumlanması için akım verilerinin sergilediği olası eğilim araştırılmıştır. Hidrometrik veriler genel itibari ile klasik istatistiksel yaklaşımlara uyum sergilemez (Bayazıt, 1995). Parametrik metodların kabul ettiği temel varsayımlar olan normallik, bağımsızlık ve homojenlik hidrometrik veri setlerinde sıklıkla sağlanamaz (Lins, 1985; Kahya ve Kalayc1, 2004). Akarsu akımının değişken olduğu hidrometrik zaman serilerinde, değişkenin zaman içerisinde 
aldığı değerler birbirinden bağımsız değildir. Çünkü ölçüm yapılan $t$ zamanına ait debi değeri, ondan önceki $t-1$ zaman dilimindeki debi değerinden etkilenmektedir (Bayazıt, 1995). Hidrometrik zaman serisi, uygulamadaki kolaylıklarından dolayı farklı dönüşümler ile normalleştirilmeye çalışılsa da her zaman anlamlı sonuçlar elde edilemeyebilir. Bu nedenle hidrometrik veri setleri üzerinden gerçekleştirilen stokastik süreçlerde parametrik olmayan yöntemler literatürde sıklıkla tercih edilmektedir (Lins ve Slack, 1999; Kahya ve Kalayc1, 2004; Özdemir ve Bahadır, 2011; Türkeş ve Deniz, 2011; Irvem, Topaloğlu ve Özfidaner, 2012; Kisi ve Ay, 2014; Tağıl ve Alevkayalı, 2014; Tekkanat ve Sarış, 2015; Altın, Sarış ve Altın, 2020; Sönmez ve Kale, 2020; Esen, 2021).

Parametrik olmayan yöntemlerin kullanımına karar vermek amacıyla kullanılan her bir gözlem istasyonuna ait akım serisine üç temel analiz uygulanmıştır. Bunlar; (i) tanımlayıcı istatistiksel bilgilerin bulunması ve $\mathrm{Z}$ test istatistiği değerleri ile birlikte yorumlanması, (ii) zaman serilerinin görsel olarak incelenmesi ve (iii) uyum iyiliği testidir. Bu kapsamda seçili AGI'lere ait akım verilerinden oluşan hidrometrik zaman serilerinin dağılım fonksiyonu incelenmiş ve Gauss Fonksiyonu'na uyumu araştırılmıştır. Çalışmada Kolmogorov-Smirnov (K-S) uyum iyiliği testi kullanılmıştır. K-S uyum iyiliği testi özellikle örneklem sayısının yüksek olduğu veri kümelerinde iyi sonuç vermesi nedeni ile sıkılıkla kullanılan bir sınama yöntemidir (Köle ve Gökpınar, 2012). K-S uyum iyiliği testinde, test istatistiği anlamlılık düzeyinin 0,05 'den büyük $(\mathrm{p}>0,05)$ olması halinde dağılımın normal dağılımdan anlamlı bir farklılık sergilemediği belirlenmiş olmaktadır (Kolmogorov, 1933; Smirnov, 1939).

Çalışmada kullanılan hidrometrik zaman serilerine ait tanımlayıcı istatistiksel parametreler ve $\mathrm{Z}$ test istatistiği değerleri Tablo 3'de verilmiştir. Tanımlayıcı istatistiksel parametreler tüm istasyonlara ait zaman serilerinin basıklık ve çarpıklık değerlerinin sıfirdan oldukça uzak, ortalama ve medyan değerleri arasındaki farkın ise çok yüksek olduğunu göstermektedir. Bu kapsamda, tanımlayıcı istatistikî parametreler dikkate alındığında istasyonlara ait zaman serilerinin normal dağılıma uyum gösterdiği söylenemez. Zaman serileri görsel olarak tümüyle sağa çarpıktır. $Z$ test istatistiği değerleri tüm istasyonlar için 0,05 anlamlılık düzeyinde $\pm 1,96$ kritik sınır değerin çok üzerindedir. $\mathrm{K}-\mathrm{S}$ uyum iyili testi sonucunda elde edilen test istatistiği anlamlılık düzeyleri sıfıra yakınsamakta ve $\mathrm{p}>0,05$ koşulunu sağlamamaktadır. Tüm bu sonuçlar ve akım verilerinin bağımsız olamama özelliği (Bayazıt, 1995) bir arada değerlendirildiğinde istasyonlara ait zaman serilerinin parametrik yöntemlere ait temel koşulları sağlamadığı kararı verilmiştir.

Elde edilen bulgulardan ve hidrometrik verilerin karakteristik özelliklerinden dolayı bu çalışmada; normallik, bağımsızlık ve homojenlik varsayımlarının aranmak zorunda olmadığı parametrik olmayan istatistiksel yöntemler tercih edilmiştir. Zaman serisinde eğilimin olup olmadığını belirlemek için Mann-Kendall (M-K) testi ve eğilimin başlangıç tarihini ortaya çıkartmak için MannKendal sıra kolelesyon test istatistiği kullanılmıştır. Söz konusu testler hidrometrik verilerin analizinde güvenilir sonuçlar vermesinden ötürü literatürde sıklıkla kullanılmaktadır (Yu, Zou ve Whittemore, 1993; Kalaycı ve Kahya, 1998; Önöz ve Bayazıt 2003; Türkeş, Koç ve Sarış, 2007; Karabulut ve Coşun 2009).

Kendall Tau testinin özel bir uygulaması olan M-K testine ait test istatistik değeri eşitlik 3 ile hesaplanır (Hirsch vd., 1982).

$$
S=\sum_{k=1}^{n-1} \sum_{J=k+1}^{n} \operatorname{sgn}\left(x_{j}-x_{k}\right)
$$

Burada $S$; M-K test istatistik değeri olmak üzere $n$; veri uzunluğu, $s g n$; işaret fonksiyonu, $x_{j}$ ve $x_{k} ; j$ ve $k$ yıllarına ait seri

Tablo 3: Zaman serilerine ait tanımlayıcı istatistiksel parametreler ve Z test istatistiği.

Table 3: Descriptive statistical parameters of time series and Z test statistics.

\begin{tabular}{|c|c|c|c|c|c|c|c|c|}
\hline & \multicolumn{2}{|c|}{ D11A002 } & \multicolumn{2}{|c|}{ D11A013 } & \multicolumn{2}{|c|}{ D11A015 } & \multicolumn{2}{|c|}{ E11002 } \\
\hline & & $\begin{array}{c}\mathrm{Z} \text { test } \\
\text { istatistiği }\end{array}$ & & $\begin{array}{c}\mathrm{Z} \text { test } \\
\text { istatistiği }\end{array}$ & & $\begin{array}{c}\mathrm{Z} \text { test } \\
\text { istatistiği }\end{array}$ & & $\begin{array}{c}\text { Z test } \\
\text { istatistiği }\end{array}$ \\
\hline Ortalama & 1,67 & & 1,52 & & 0,41 & & 0,45 & \\
\hline Minimum & 0,00 & & 0,00 & & 0,00 & & 0,00 & \\
\hline Maksimum & 12,58 & & 12,40 & & 4,26 & & 4,03 & \\
\hline Medyan & 0,59 & & 0,40 & & 0,10 & & 0,17 & \\
\hline Varyans & 5,99 & & 5,10 & & 0,41 & & 0,41 & \\
\hline Standard sapma & 2,45 & & 2,26 & & 0,64 & & 0,64 & \\
\hline Çarpıklık & 2,11 & 19,85 & 1,90 & 17,91 & 2,55 & 23,42 & 2,48 & 23,61 \\
\hline Çarpıklık std. hata & 0,11 & & 0,11 & & 0,11 & & 0,11 & \\
\hline Basıklık & 4,48 & 21,09 & 3,47 & 16,37 & 7,53 & 34,66 & 7,07 & 33,69 \\
\hline Basıklık std. hata & 0,21 & & 0,21 & & 0,22 & & 0,21 & \\
\hline
\end{tabular}


değerleridir ( $\mathrm{j}>\mathrm{k}$ koşulunu sağlamak şartıyla). İşaret fonksiyonu $x_{j}$ ve $x_{k}$ değerlerinin kıyaslanmasına dayanan eşitlik 4 yardımı ile bulunur (Hirsch vd., 1982).

$\operatorname{sgn}\left(x_{j}-x_{k}\right)=\left\{\begin{array}{l}x_{j}>x_{i} \Rightarrow 1 \\ x_{j}=x_{i} \Rightarrow 0 \\ x_{j}<x_{i} \Rightarrow-1\end{array}\right.$

Asimptotik olarak, normal bir dağılıma sahip ve ortalaması sıfır olan M-K test istatistiğinin varyansı eşitlik 5 yardımı ile bulunur (Hirsch vd., 1982).

$$
\operatorname{var}(S)=\frac{1}{18}\left[n(n-1)(2 n+5)-\sum_{i=1}^{k} t_{i}\left(t_{i}-1\right) 2\left(t_{i}+5\right)\right]
$$

Burada $\operatorname{Var}(S)$; M-K test istatistiği varyansı olmak üzere $k$; veri setindeki bağıl (benzer) grupların sayısını, $t_{i} ; i$ uzunluğundaki bir seride benzer olan gözlemleri ifade etmektedir. $n \geq 10$ koşulu altında $\mathrm{M}-\mathrm{K}$ test istatistiğinin teorik olasılık dağılımı normal dağılıma benzemektedir (Hirsch vd., 1982). Buna göre kritik Z değeri eşitlik 6 yardımı ile belirlenir.

$$
Z=\left\{\begin{aligned}
S>0 \Rightarrow & \frac{S-1}{\sqrt{\operatorname{Var}(S)}} \\
S=0 & \Rightarrow 0 \\
S<0 \Rightarrow & \frac{S+1}{\sqrt{\operatorname{Var}(S)}}
\end{aligned}\right.
$$

Bir eğilim olup olmadığına; kritik $\mathrm{Z}$ değeri ve istenen anlamlılık seviyesine $(\alpha)$ göre normal dağglım tablosundan tespit edilen $Z_{\alpha / 2}$ değerinin karşılaştırılması ile karar verilir. Kritik Z'nin mutlak değeri, $Z_{\alpha / 2}$ değerinden büyük $\left(|Z|>Z_{\alpha / 2}\right)$ ise zaman serisinde anlamlı bir eğilim bulunmaktadır. Aksi durumda eğilimin varlı̆̆ından söz edilemez. Anlamlı bir eğilim tespit edilmesi halide eğilimin yönüne $M-K$ test istatistik değeri ile karar verilebilir. Pozitif değer artan bir eğilimin, negatif değer ise azalan bir eğilimin işaretçisidir.

Parametrik olmayan M-K sira korelasyon testi, zaman serisinde yer alan verilerin büyüklüğünden $\left(x_{i}\right)$ çok veri seti sırasını $\left(y_{i}\right)$ dikkate alarak, bir serideki olası eğilimin yönünü ve istatistiksel momentini vermektedir (Türkeş, 1996a; Türkeş, Sümer ve Demir, 2002). M-K sira korelasyon testinde $x_{i}$ yerine $y_{i}$ kullanılır. M-K sıra korelasyon testinde her bir $y_{i}$ değeri için $(i>$ $j$ koşulunu sağlaması şartıyla) kendisinden önce gelen veri kümesi elemanlarının $\left(y_{i}\right)$ sayısı $\left(n_{i}\right)$ bulunur. Toplam $n_{i}$ değerlerinin bulunması ile test istatistiği $(t)$ elde edilir. Orijinal veri kümesine ait $t$ değeri eşitlik 7 yardımıyla bulunur (Sneyers, 1990; Türkeş, 1996a; Toros, 2012).

$$
t=\sum_{i=1}^{n} n_{i}
$$

Elde edilen dağılım fonksiyondan itibaren $\mathrm{M}-\mathrm{K}$ sıra korelasyon test istatistik değeri eşitlik 8 yardımı ile belirlenir (Sneyers, 1990; Türkeş, 1996a; Toros, 2012).

$$
u(t)=\frac{t-E(t)}{\sqrt{\text { vart }}}
$$

Burada, $u(t)$; M-K sıra korelasyon test istatistiği değeri, $t$; test istatistik değeri; $E(t)$; test istatistiği ortalamasını ve var $(t)$; test istatistiği varyansını ifade eder (Sneyers, 1990; Türkeş 1996a). Test istatistiğine ait ortalama ve varyans değerleri ise surasıyla eşitlik 9 ve 10 yardımı ile hesaplanır (Sneyers, 1990; Türkeş, 1996a; Toros, 2012).

$$
\begin{aligned}
& E(t)=\frac{n(n-1)}{4} \\
& \operatorname{var}(t)=\frac{n(n-1)(2 n+5)}{72}
\end{aligned}
$$

Elde edilen $u(t)$ değerinin sıfıra yaklaşması zamana göre bir değişim (eğilim) olmadığı varsayımını doğrular (Sneyers, 1990). Aksi durum ise bir değişimin (eğilimin) olduğunu ifade eder. Pozitif $u(t)$ değeri artan bir eğilimin, negatif $u(t)$ değerleri ise azalan bir eğilimin işaretçisidir (Sneyers, 1990). M-K sıra korelasyon test istatistiği grafiksel olarak eğilimi sunar. Test istatistiği $u(t)$ ve geriye doğru test istatistiği $u^{\prime}(t)$, eğilimin başladığı yerde birbirine yaklaşır, birbirlerini keser ve daha sonra birbirlerinden uzaklaşır. Eğer herhangi bir eğilim yoksa $u(t)$ ve $u^{\prime}(t)$ birbirlerine defalarca yaklaşarak yakın bir salınım geometrisi çizer (Sneyers, 1990). $u(t)$ ve $u^{\prime}(t)$ kesişim noktası eğilimin başlangıcını vermesi açısından önemlidir.

\section{BULGULAR}

Çalışmada kullanılan akım gözlem istasyonlara ait uzun dönem ortalama aylık akımlar ile Akşehir (1960 - 2016) ve Çay (1984-2012) meteoroloji gözlem istasyonlarına ait yağış yüksekliği değerleri Şekil 2'de verilmiştir. Çalışma dönemi boyunca en yüksek ortalama aylık akım değerleri D11A002, D11A013 ve D11A015 numaralı ölçüm istasyonlarında nisan ayında, E11002 numaralı ölçüm istasyonunda ise mart ayında kaydedilmiştir. D11A002, D11A013, D11A015 ve E11002 numaralı istasyonlarda kaydedilen en yüksek ortalama aylık akımlar sirası ile $5,46 \mathrm{~m}^{3} / \mathrm{sn}, 4,37 \mathrm{~m}^{3} / \mathrm{sn}, 1,69 \mathrm{~m}^{3} / \mathrm{sn}$ ve $1,17 \mathrm{~m}^{3} /$ sn'dir. En düşük ortalama aylık akım değerleri D11A002 ve D11A013 numaralı istasyonlarda eylül ayında; D11A015 
numaralı istasyonda ağustos ayında ve E11002 numaralı istasyonda ise temmuz ayında kaydedilmiştir. D11A002, D11A013, D11A015 ve E11002 numaralı istasyonlarda kaydedilen en düşük ortalama aylık akım değerleri sırası ile 0,05 $\mathrm{m}^{3} / \mathrm{sn}, 0,08 \mathrm{~m}^{3} / \mathrm{sn}, 0,02 \mathrm{~m}^{3} / \mathrm{sn}$ ve $0,08 \mathrm{~m}^{3} / \mathrm{sn}^{\prime}$ dir. İstasyonlarda temmuz, ağustos ve eylül ayları akım değerlerinin en düşük seviyede ölçüldüğü aylar; mart ve nisan ayları ise akım değerlerinin en yüksek seviyede ölçüldüğü aylar olarak karşımıza çıkmaktadır. Havza genelinde akım değerleri oldukça düşüktür. Özellikle temmuz ve ağustos aylarında akım değerlerinin sıfıra çok yaklaşması ve sıfır olması ilgili aylarda dönemsel akarsu kurumalarının olduğunu göstermektedir. Genel olarak yüksek ve düşük akımların kaydedildiği aylar, yüksek ve düşük yağış yüksekliklerinin kaydedildiği aylar ile uyum göstermektedir (Şekil 2). Ortalama akım değerlerinden pozitif yönlü sapmanın en yüksek olduğu aylar kış mevsimi sonları ile ilkbahar mevsiminde kümelenmiştir. Bu durum tipik olarak karasal İç Anadolu yağış rejimi özellikleri ile uyum sergilemektedir. Ayrıca karma rejim özellikleri sergileyen Akarçay Kapalı Havzası'ndaki kar yağışları ve ilkbahar yağmurlarının havzadaki akarsuların besleniminde son derece önemli bir yere sahip olduğu anlaşılmaktadır.

Çalışmada kullanılan seçili istasyonlara ait farklı referans dönemler $(k=1,2,3,4)$ için elde edilen \%SDI değerleri istasyon bazlı olarak Şekil 3'de verilmiştir. Çalışma sonuçları farklı referans dönemler boyunca kaydedilen kurak yıl sayılarının birbirine yakın olduğunu göstermektedir. Hidrolojik kuraklık, tüm referans dönemler boyunca farklı SDI sınıf aralıklarında gerçekleşmiştir.

Gözlem istasyonlarında en fazla sayıda kurak yıl $k=1$ referans döneminde kaydedilmiştir. $k=1$ referans dönemi için D11A002, D11A013, D11A015 ve E11002 numaralı istasyonlarda $\mathrm{SDI}<0$ koşulunu sağlayan kurak yıllar; toplam gözlem süresinin sirası ile $\% 47, \% 42, \% 62$ ve $\% 64$ 'ünü oluşturmaktadır. Kaydedilen kurak yıllar $k=1$ referans döneminde hafif kurak ve orta derece kurak sınıf aralıklarında kümelenmiştir. Bu durum görece yağışılı olan ayları temsil eden $k=1$ referans döneminde hidrolojik kuraklığın izlerinin arttığını göstermektedir. Gözlem süresi boyunca Akşehir Gölü drenaj alanı içerisinde yer alan D11A015 numaralı AGI ve Afyon Ovası'nın kuzeyinde yer alan E11002 numaralı AGI'de kaydedilen yüksek sayıdaki hidrolojik kurak yıl sayısı; havza kuzey ve güneyinde ekim, kasım ve aralık aylarında farklı su yıllarında hidrolojik kuraklığın egemen olduğunu göstermektedir. D11A015 numaralı AGI'de şiddetli kurak ve aşırı kurak sınıf aralıklarında; E11002 numaralı AGI'de şiddetli kurak sınıf aralığında SDI değerlerine sahip su yıllarının olması hidrolojik kuraklığın çok ciddi boyutlara ulaştığını göstermesi açısından önemlidir.

Akarçay Kapalı Havzası'nda $k=2$ referans dönemi boyunca D11A002, D11A013, D11A015 ve E11002 numaralı istasyonlarda $\mathrm{SDI}<0$ koşulunu sağlayan kurak yıllar; toplam gözlem süresinin sirası ile $\% 47, \% 51, \% 53$ ve $\% 56$ 'sinı
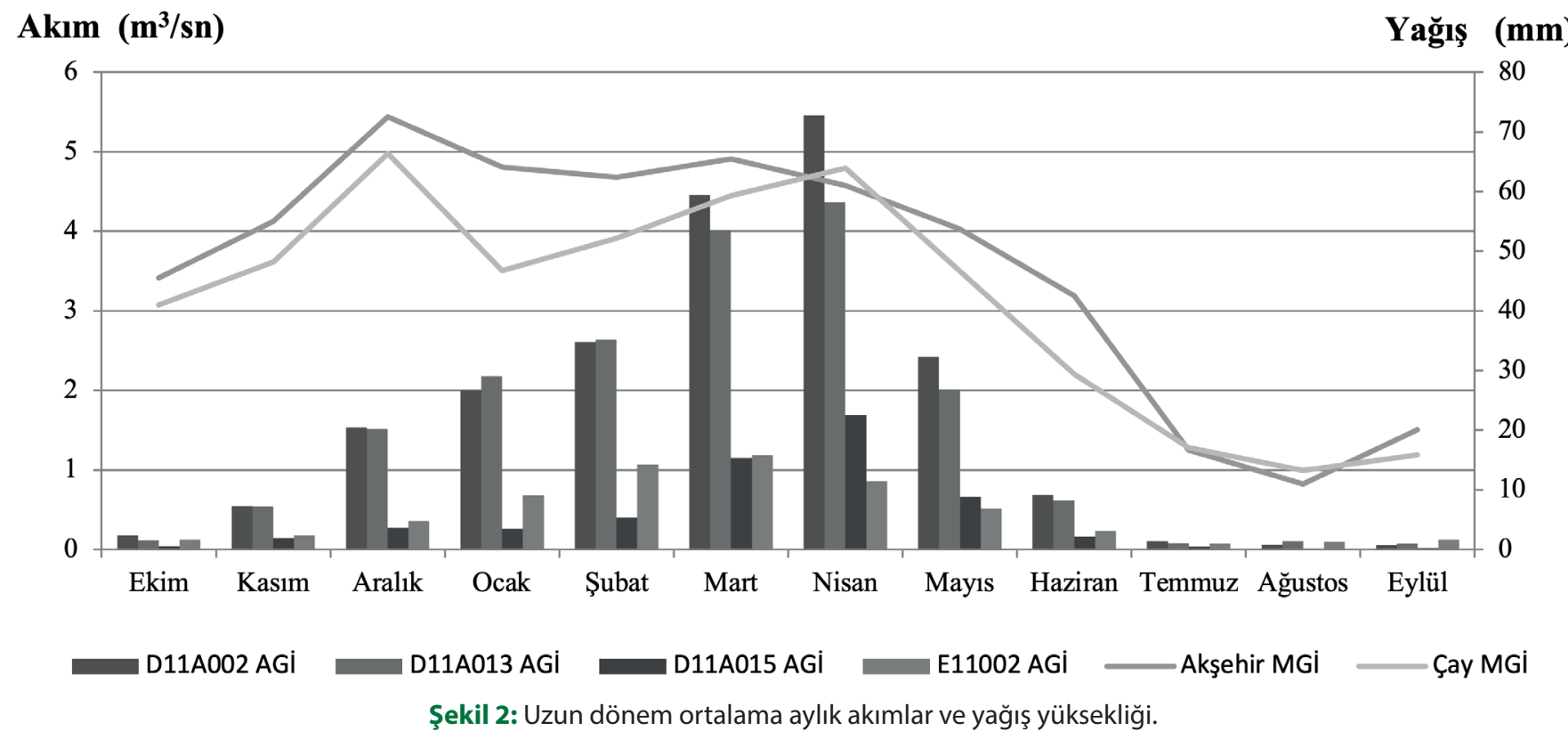

Figure 2: Long-term average monthly streamflows and precipitation. 

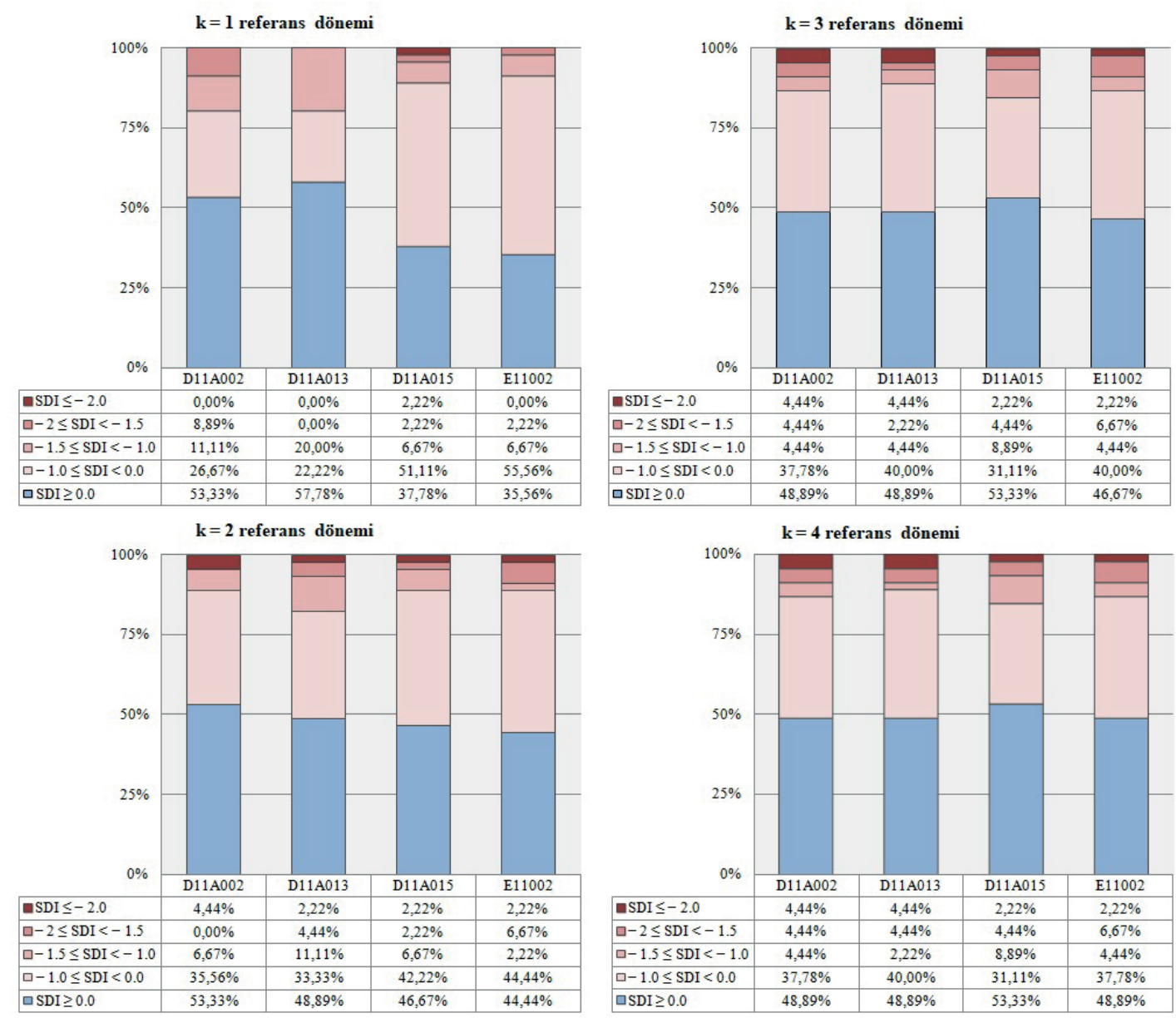

Şekil 3: Farklı referans dönemler için SDI (\%) sayısı.

Figure 3: Number of SDI (\%) for different periods.

oluşturmaktadır. $k=2$ referans dönemi için SDI değerleri hafif kurak sınıf aralığında kümelenmiştir. $k=2$ referans dönemi Akarçay Kapalı Havzası'nda en fazla yağış alan ayları temsil etmektedir. Bununla birlikte tüm istasyonlarda aşırı kurak sınıf aralığına giren SDI değerlerine sahip su yılları yer almaktadır. Özellikle aşırı kurak sınıf aralığındaki su yılları Akşehir Gölü su toplama alanında yer alan istasyonlarda daha fazla sayıda kaydedilmiştir. $\mathrm{Bu}$ durum $k=1$ referans dönemine benzer şekilde, Akarçay Kapalı Havzası güney batısında yer alan Akşehir Alt Havzası'nda hidrolojik kuraklığın oldukça ciddi boyutlara ulaştığını göstermektedir.

Akarçay Kapalı Havzası'nda $k=3$ referans dönemi boyunca D11A002, D11A013, D11A015 ve E11002 numaral1 istasyonlarda $\mathrm{SDI}<0$ koşulunu sağlayan kurak yıllar; toplam gözlem süresinin siras1 ile $\% 51, \% 51, \% 47$ ve $\% 53$ 'ünü oluşturmaktadır. $k=3$ referans dönemi için SDI değerleri hafif kurak sınıf aralığında kümelenmiştir. Buna karşın tüm istasyonlar için aşırı kurak ve şiddetli kurak sınıf aralıklarında yer alan su yılları sayısında önemli bir artış kaydedilmiştir. İstasyon konumları dikkate alındığında Şuhut, Afyon ve Akşehir alt havzalarında ciddi hidrolojik kuraklık izleri tespit edilmiştir.

Akarçay Kapalı Havzası'nda $k=4$ referans dönemi için D11A002, D11A013, D11A015 ve E11002 numaralı istasyonlarda $\mathrm{SDI}<0$ koşulunu sağlayan kurak yıllar; toplam gözlem süresinin sırası ile $\% 51, \% 51, \% 47$ ve $\% 51$ 'ini oluşturmaktadır. SDI hesaplamalarında $k=4$ referans dönemi tüm su yılını temsil etme özelliğine sahiptir. Her ne kadar $k=4$ referans dönemi için SDI değerleri hafif kurak sınıf aralığında kümelense de D11A002, D11A013, D11A015 ve E11002 numaralı istasyonlarda aşırı kurak ve şiddetli kurak sınıf aralıklarında yer alan kurak yıllar; toplam gözlem süresinin sırası ile $\% 9, \% 9, \% 7$ ve $\% 9$ 'unu oluşturmaktadır. İstasyonların konumları dikkate alındığında; Eber Gölü drenaj sahası içerisinde yer alan Afyon ve Şuhut ovaları ile Akşehir Gölü drenaj alanında yer alan Akşehir Ovası'nda hidrolojik kuraklığın çok şiddetli yaşandığı dönemler gerçekleştiği tespit edilmiştir. 
İstasyon bazlı SDI değerleri su yıllarına göre Şekil 4'de verilmiştir. İstasyon bazında uzun dönem SDI değerleri incelendiğinde, hidrolojik olarak kurak ve kurak olmayan dönemlerin 1980'lere kadar beşer y1llık kısa süreli dalgalanmalarla birbirini takip ettiği anlaşılır. İstasyon bazlı değişimler olmakla birlikte genel olarak kırk beş yıllık uzun dönem verilerine göre 1980 'lerin ortası dönüm noktası olarak bulunmuştur. Su yılını temsil eden referans dönem boyunca 1980'lerin ortasından itibaren tüm istasyonlarda hidrolojik kuraklığın baskın hale geldiği tespit edilmiştir. Dönüm noktasından sonraki su yıllarında hidrolojik kurak olmayan dönemler olmakla birlikte bu dönemlerin genliği ve süresi net bir şekilde azalmıştır. $k=4$ referans dönemi boyunca on dört su yılına ait zaman serisinde eş zamanlı olarak tüm istasyonlarda hidrolojik kuraklık izine rastlanmıştır $(\mathrm{SDI}<0)$. Eş zamanlı hidrolojik kuraklık tespit edilen su yıllarının tamamı 1986-1987 ve sonrasındaki su yıllarında kümelenmektedir. 1994-1995 su yılı ise tüm istasyonlar için şiddetli kuraklı̆̆ın kaydedildiği su yıl olarak karşımıza çıkmaktadır. Referans dönem $k=4$ için on üç su yılında hiçbir istasyona ait zaman serisinde hidrolojik kuraklık izine rastlanmamıştır (SDI $\geq 0)$. Söz konusu on üç su yılı $1984-$ 1985 su yılı ve öncesine kümelenmektedir. Bu durum 1980’lerin ortasından sonra baskın hale gelen hidrolojik kuraklı̆̆ın bir diğer göstergesidir. Burada dikkat çeken nokta tüm istasyonlar için
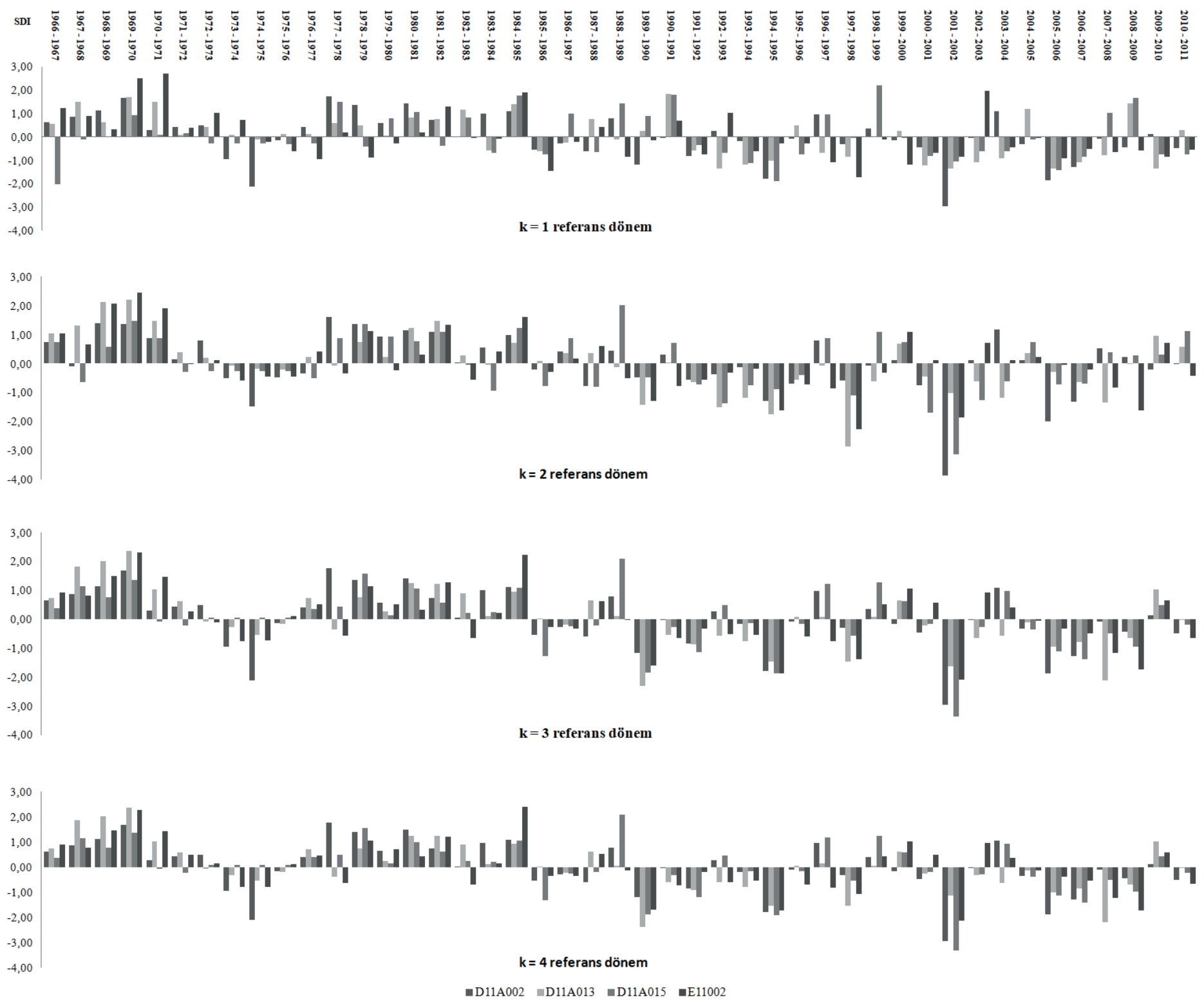

Şekil 4: Farklı referans dönemler için su yıllarına göre SDI değerleri.

Figure 4: SDI of different periods by water years. 
kurak geçen su yıllarına ait frekansının günümüze yaklaştıkça artmasıdır. Benzer şekilde $k=1, k=2$, ve $k=4$ referans dönemlerinde de net bir şekilde günümüze yaklaştıkça artan sayı ve değerde hidrolojik kuraklık tespit edilmiştir.

M-K testine ait kritik Z değerleri ve M-K sıra korelasyon test istatistiği değerleri Tablo 4'de verilmiştir. SDI indis referans dönemleri dikkate alınarak $u(t)$ ve $u^{\prime}(t)^{\prime}$ ler hesaplanmıştır. Anlamlı eğilimin tespit edildiği istasyonlar için $u(t)$ ve $u$ ' $(t)$ grafiklerinden itibaren eğilimlere ait başlangıç tarihleri belirlenmiştir (Şekil 5, Şekil 6, Şekil 7 ve Şekil 8). Çalışma sonuçlarına göre, D11A002, D11A013 ve E11002 numaralı AGI'lerin tamamında tüm referans dönemler boyunca $\% 95$ güven aralığında $(\alpha=0,05)$ anlamlı bir azalma eğilimi tespit edilmiştir. D11A015 numaralı istasyonda $k=1$ ve $k=2$, referans dönemleri için 0,05 anlamlılık düzeyinde herhangi bir eğilim tespit edilememiş, diğer referans dönemlerinde ise çalışmada yer alan istasyonlarda elde edilen bulgulara benzer şekilde negatif yönlü bir eğiliminin varlığı tespit edilmiştir. Grafiklerden hareketle her bir referans dönem için eğilimin başlangıç tarihine karar verilmiştir. D11A002 numaralı AGI'ye ait hidrometrik zaman serisinde $k=1, k=2, k=3$ ve $k=4$ referans dönemleri için tespit

Tablo 4: İstasyon bazlı eğilimler ve başlangıç tarihleri (\%95 güven aralığında $\pm 1,96$ kritik değere göre). Table 4: Gauging station based trends and dates (critical significance value of \pm 1.96 at $95 \%$ confidence interval).

\begin{tabular}{|c|c|c|c|c|c|c|}
\hline İstasyon & $\mathbf{k}$ & Test Z & $u(t)$ & Eğilim & Yön & Başlangıç tarihi \\
\hline D11A002 & 1 & $-3,21$ & $-3,23$ & var & $\downarrow$ & 1993 \\
\hline D11A002 & 2 & $-2,78$ & $-2,79$ & var & $\downarrow$ & 1986 \\
\hline D11A002 & 3 & $-3,26$ & $-3,27$ & var & $\downarrow$ & 1989 \\
\hline D11A002 & 4 & $-3,20$ & $-3,21$ & var & $\downarrow$ & 1989 \\
\hline D11A013 & 1 & $-3,55$ & $-3,63$ & var & $\downarrow$ & 1985 \\
\hline D11A013 & 2 & $-3,69$ & $-3,70$ & var & $\downarrow$ & 1982 \\
\hline $\mathrm{D} 11 \mathrm{~A} 013$ & 3 & $-3,87$ & $-3,89$ & var & $\downarrow$ & 1985 \\
\hline $\mathrm{D} 11 \mathrm{~A} 013$ & 4 & $-3,82$ & $-3,83$ & var & $\downarrow$ & 1985 \\
\hline $\mathrm{D} 11 \mathrm{~A} 015$ & 1 & $-1,45$ & $-1,52$ & yok & --- & --- \\
\hline D11A015 & 2 & $-1,81$ & $-1,85$ & yok & -- & --- \\
\hline D11A015 & 3 & $-2,92$ & $-2,94$ & var & $\downarrow$ & 1988 \\
\hline D11A015 & 4 & $-3,07$ & $-3,12$ & var & $\downarrow$ & 1988 \\
\hline E11002 & 1 & $-3,09$ & $-3,12$ & var & $\downarrow$ & 1973 \\
\hline E11002 & 2 & $-2,34$ & $-2,36$ & var & $\downarrow$ & 1971 \\
\hline E11002 & 3 & $-2,59$ & $-2,62$ & var & $\downarrow$ & 1971 \\
\hline E11002 & 4 & $-2,71$ & $-2,76$ & var & $\downarrow$ & 1971 \\
\hline
\end{tabular}
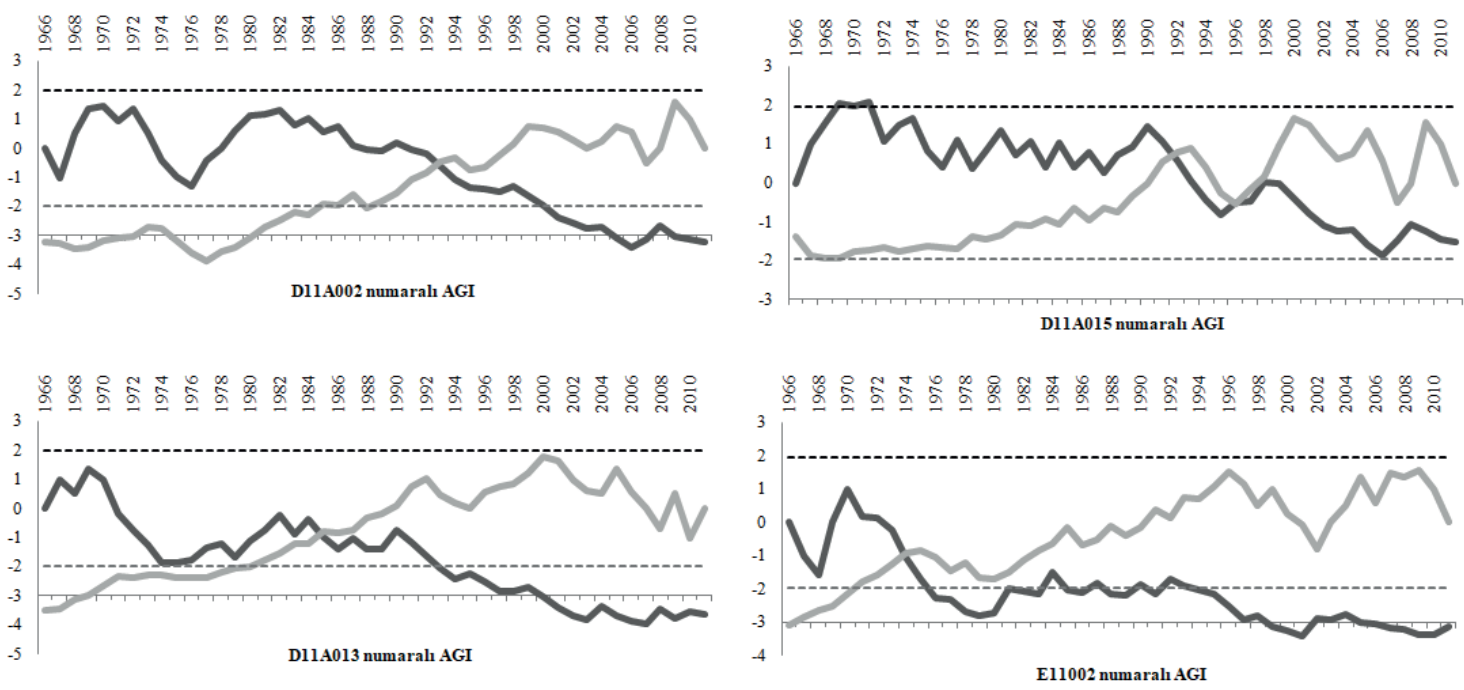

$$
u(t)=u^{\prime}(t) \quad-\cdots--1,96---\cdot 1,96
$$

Şekil 5: referans dönemi için M-K sıra korelasyon test istatistiği grafiği (\%95 güven aralığında $\pm 1,96$ kritik değere göre).

Figure 5: Graphs of Mann-Kendall rank correlation test statistic for reference period (critical significance value of \pm 1.96 at $95 \%$ confidence interval). 

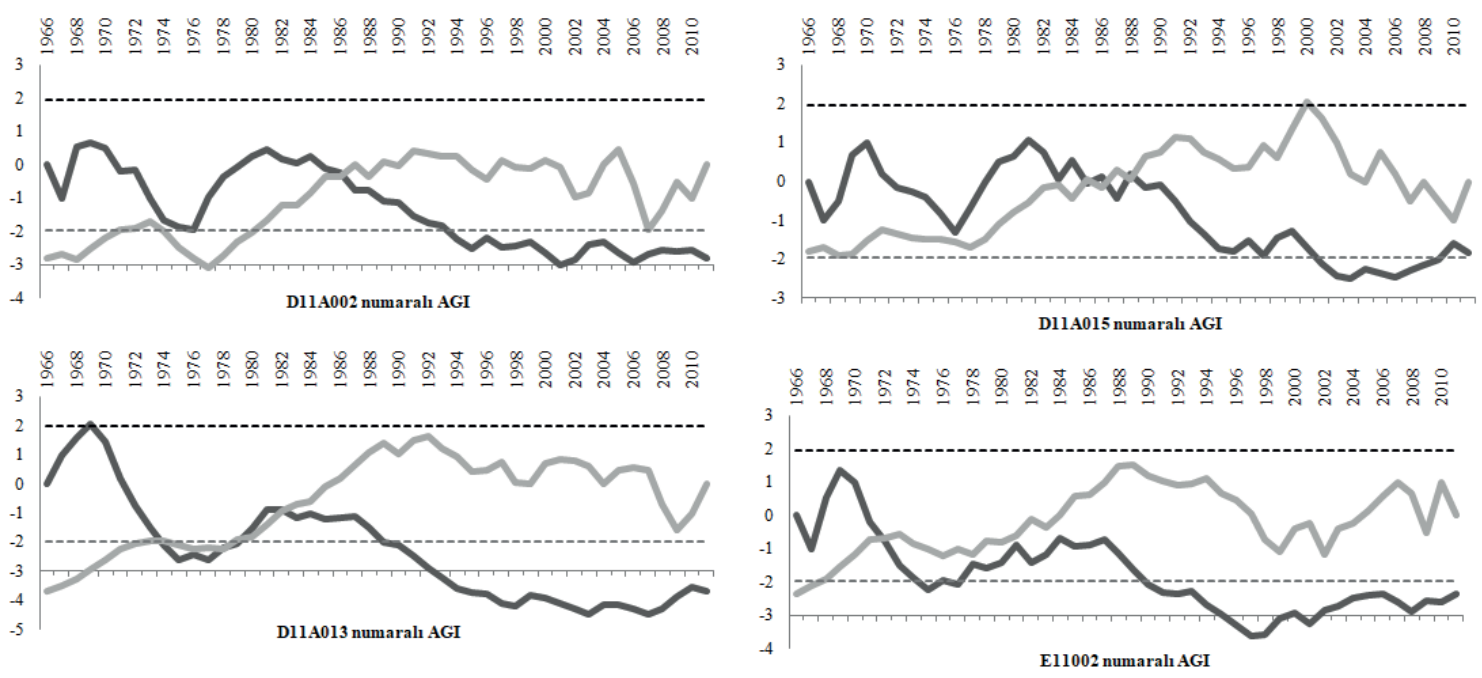

$\mathrm{u}^{(\mathrm{t})}=\mathrm{u}^{\prime}(\mathrm{t})$

$1,96 \quad----\cdot-1,96$

Şekil 6: referans dönemi için M-K sıra korelasyon test istatistiği grafiği (\%95 güven aralığında $\pm 1,96$ kritik değere göre).

Figure 6: Graphs of Mann-Kendall rank correlation test statistic for reference period (critical significance value of \pm 1.96 at $95 \%$ confidence interval).
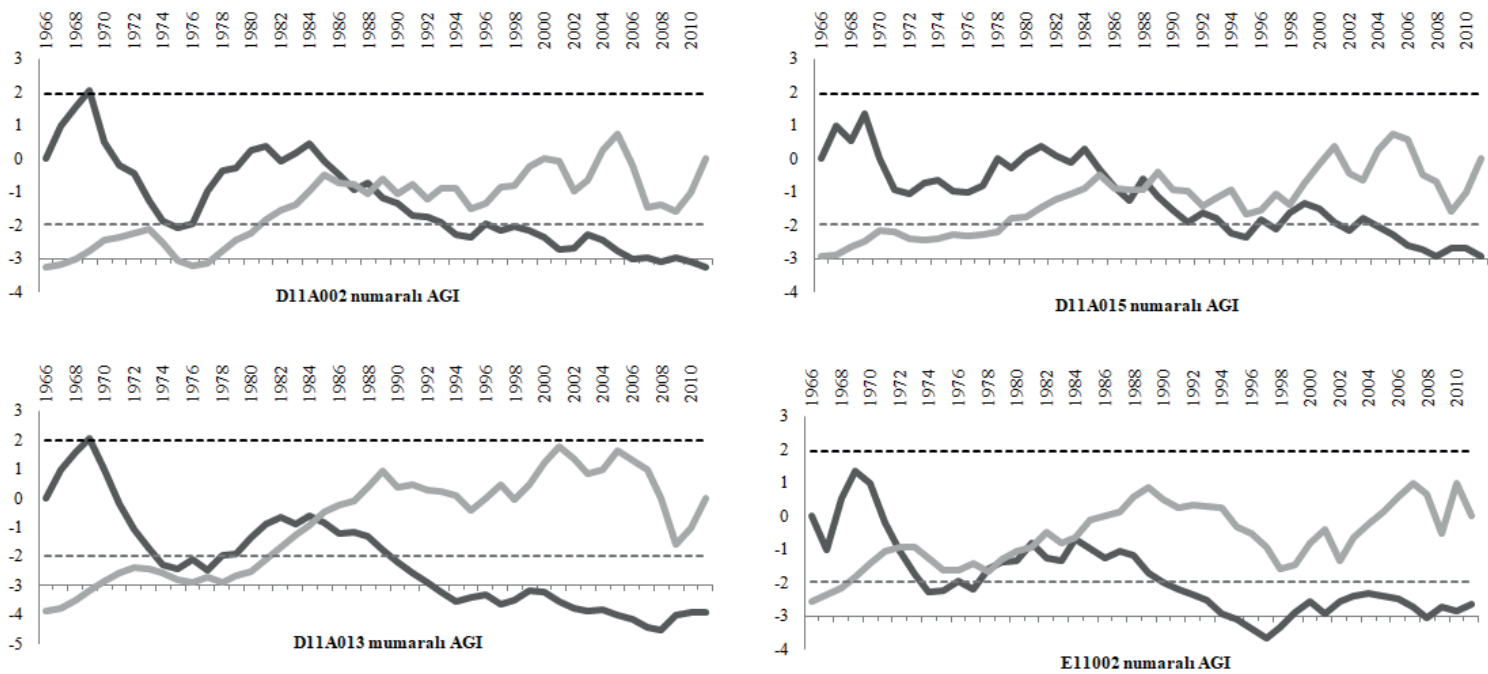

$u^{u(t)}{ }_{u^{\prime}(t)} \quad----\cdot 1,96 \quad----\cdot-1,96$

Şekil 7: Referans dönemi için M-K sıra korelasyon test istatistiği grafiği (\%95 güven aralığında $\pm 1,96$ kritik değere göre).

Figure 7: Graphs of Mann-Kendall rank correlation test statistic for reference period (critical significance value of \pm 1.96 at $95 \%$ confidence interval).

edilen eğilimlerin başlangıç tarihleri sırası ile 1993, 1986, 1989 ve 1989 yıllarıdır. D11A013 numaralı AGI'ye ait hidrometrik zaman serisinde $k=1, k=2, k=3$ ve $k=4$ referans dönemleri için tespit edilen eğilimlerin başlangıç tarihleri sırası ile 1985, 1982, 1985 ve 1985 y1llarıdır. D11A015 numaralı AGI'ye ait hidrometrik zaman serisinde $k=3$ ve $k=4$ referans dönemleri için tespit edilen eğilimlerin başlangıç tarihi 1988 yılıdır. E11002 numaralı
AGI'ye ait hidrometrik zaman serisinde $k=1$ referans dönemi için eğilimin başlangıç tarihi 1973 olarak belirlenmiştir. Aynı istasyona ait zaman serisi için $k=2, k=3$ ve $k=4$ referans dönemlerine ait eğilimlerin başlangıç tarihi ise 1971 yılı olarak belirlenmiştir. Negatif yönlü eğilimlerin başlangıç tarihleri genel olarak 1980'li yılların ikinci yarısı ve sonrasında kümelenmektedir. Her ne kadar E11002 numaralı istasyon için 1971 y1lından 

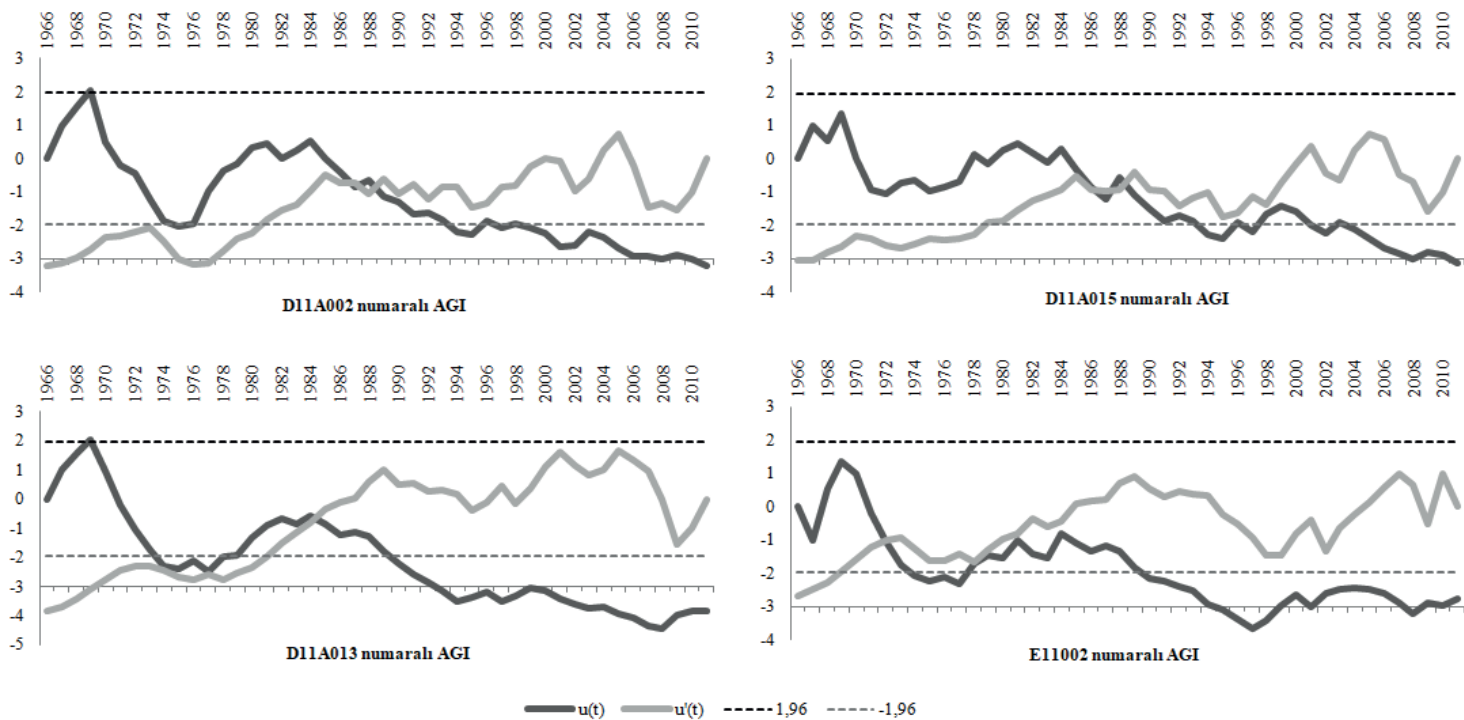

Şekil 8: referans dönemi için M-K sıra korelasyon test istatistiği grafiği (\%95 güven aralığında $\pm 1,96$ kritik değere göre).

Figure 8: Graphs of Mann-Kendall rank correlation test statistic for reference period (critical significance value of \pm 1.96 at $95 \%$ confidence interval).

itibaren azalan yönlü bir eğilim başlamış olsa da 1980'lerin sonundan itibaren eğilimin daha anlamlı $\left(u^{\prime}(t)> \pm 1,96\right.$ koşulu belirginleşmiştir) bir hale ulaştı̆̆ anlaşılmaktadır.

SDI değerleri ve M-K sıra korelasyon test istatistiği bulguları bir arada değerlendirildiğinde tutarlı bulgulara ulaşılmıştır. Genel olarak $u(t)$ ve $u^{\prime}(t)^{\prime}$ nin zamana göre değişimini gösteren grafiklerden elde edilen anlamlı eğilimin gerçekleştiği tarihler SDI değerlerine göre dönüm noktası olarak tanımlanan tarih ile benzerlik göstermektedir. $k=4$ referans dönemi için D11A002 numaralı istasyonda azalış eğiliminin başladığı 1989 su yılından sonraki zamanın \%77'sinde, D11A013 numaralı AGİ için azalış eğiliminin başladığı 1985 su yılından sonraki zamanın \%69'unda, D11A015 numaralı AGİ için azalış eğiliminin başladığı 1988 su yılından sonraki zamanın \%70'inde hidrolojik kuraklık $(\mathrm{SDI}<0)$ tespit edilmiştir. E11002 numaralı AGİ için azalış eğiliminin başladığı 1971 su yılından sonraki zamanın \%58'inde, eğilimin daha anlamlı olduğu 1990 su yılından sonraki zamanın ise \%71'inde hidrolojik kuraklık (SDI $<0$ ) tespit edilmiştir. Bir başka ifade ile su yılı dikkate alındığında azalış eğiliminin başladığı tarihten sonraki su yılları boyunca $\mathrm{SDI}<0$ koşulunun sağlandığı süre, zamanın \%70'indan fazla bir kısmını kapsamaktadır. Bu durum, çalışma sahasından gerçekleşmiş olan hidrolojik kuraklığın büyüklüğünü sergilemesi açısından oldukça önemlidir.

E11002 ve D11A013 numaralı istasyonlar Eber Gölü drenaj alanında sırasıyla Afyon ve Şuhut alt havzalarında yer alırken D11A002 ve D11A015 numaralı istasyonlar doğrudan Akşehir
Gölü drenaj alanında yer almaktadır. Çalışma bulguları, istasyonların konumları ile bir arada değerlendirildiğinde gözlem süresi boyunca artan bir genlik ile özellikle Afyon, Şuhut ve Akşehir ovaları ile temsil edilen alt havzalarda ciddi boyutlara oluşan hidrolojik kurak su yıllarının yaşandığı belirlenmiştir. Havzada yer alan göllerin besleniminde yeraltı suyunun çok büyük bir katkısı bulunmamaktadır (Tezcan vd., 2002). Bu bağlamda, akarsularda gerçekleşecek hidrolojik kuraklığa bağlı olarak akım değerlerindeki azalma kuşkusuz sulak alanlar üzerinde negatif yönlü alansal değişiklikler meydana gelmesine neden olacaktır. Akarçay Kapalı Havzası'nda çizgisel akışa geçen suların nihai alıcı ortamı Eber ve Akşehir gölleridir. Eber ve Akşehir gölleri, Taşköprü Çayı tarafından gerçekleştirilen doğal akış ile birbirlerine bağlıdır. Bir başka ifade ile Eber Gölü drenaj sahasında yaşanacak hidrolojik kuraklık öncelikli olarak Eber Gölü'nü akabinde ise Akşehir Gölü'nü etkileyecektir. Akşehir Alt Havzası'nda yaşanacak hidrolojik kuraklık ise doğrudan Akşehir Gölü’nü etkileyecektir. Bu kapsamda; hidrolojik kuraklık ile göllerin beslenimi arasındaki matematiksel model bu çalışmanın konusu olmamakla birlikte tespit edilen hidrolojik kuraklık bulguları, her iki göldeki negatif yönlü alansal değişimleri desteklemektedir.

\section{SONUÇ VE TARTIŞMA}

Akarçay Kapalı Havzası'ndaki hidrolojik kuraklığa ait izlerin SDI değerleri ile araştırıldığı ve olası eğilimler ile birlikte değerlendirildiği bu çalışmanın sonuçları iki temel grupta toplanabilir. 
(i) Akarçay Kapalı Havzası'nda yer alan seçili istasyonlarda 1966 - 2011 dönemi boyunca hidrolojik kuraklığa ait izler tespit edilmiştir. SDI $<0$ koşulunu sağlayan SDI değerleri ve eğilim analizleri ile elde edilen negatif eğilim yönü söz konusu bulgunun temel dayanaklarıdır.

(ii) Akarçay Kapalı Havzası'nda yer alan seçili istasyonlar için hidrolojik kuraklığın dönüm noktası 1980'lerin ortasıdır. Bu tarihten sonra tüm istasyonlarda hidrolojik kuraklık genliği ve süresi net bir şekilde artmıştır. $\mathrm{Bu}$ sonuç, istasyonlarda kaydedilen negatif yönlü eğilimlerin başlangıç tarihleri ve anlamlılık düzeyleri ile desteklenmektedir.

Çalışma bulguları literatürde yer alan farklı çalışmalara ait bulgularla uyumludur. Kahya ve Kalaycı (2004), Türkiye geneli için akarsu akımlarındaki eğilimi araştıdıkları çalışmalarında Akarçay Kapalı Havzası'ndaki akım eğilimlerini belirlemek için E11002 numaralı AGI'ye ait 1965 - 1993 su yılları arasındaki zaman serisini kullanmışlardır. Söz konusu çalışmanın bulguları arasında yer alan akarsu akımlarındaki negatif yönlü eğilimin bu çalışma sonuçlarına göre devam ettiği görülmektedir. Genel olarak hidrolojik kuraklık, meteorolojik kuraklıktan sonra ortaya çıkmakta ve meteorolojik kuraklık bileşenlerine bağımlı olarak gelişen dinamik bir sürece sahiptir. Özellikle negatif yönlü yağış eğilimleri ve eğilimin süresi öncelikle meteorolojik kuraklığın akabinde ise hidrolojik kuraklı̆̆ın gelişmesinde önemli bir rol üstlenir. Bu çalışmada SDI değerleri ile tespit edilen ve eğilim analizleri ile anlamlılığı araştırılan hidrolojik kuraklığa ait bulguların, gerçekleşmiş olan meteorolojik kuraklığın bir sonucu olduğu varsayımı dikkate alındığında havza genelinde yağışların negatif yönlü bir eğilim göstermiş olması gerekmektedir. Söz konusu eğilimin varlığ kuraklık Sönmez vd. (2005), Türkeş (1996b), Türkeş vd. (2007), Türkeş (2012), Akbaş (2014), Kuzay ve Tombul (2020) tarafından geçekleştirilen farklı çalışmaların sonuçları arasında yer almaktadır.

Havza tabanında yer alan Eber ve Akşehir gölleri ciddi boyutlara ulaşan negatif yönlü alansal değişimler kaydedilmiştir (Sener vd., 2010; Yıldırım vd., 2011; Bahadır, 2013; Köle vd., 2016; Kale, 2018). Bu durum yerüstü su kaynakları ile beslenen göllere ulaşan akımlarda ciddi azalmalar olması gerektiği savını ortaya çıkartmaktadır. Akarçay Kapalı Havzası'nda tespit edilen $\mathrm{SDI}<0$ koşulunu sağlayan kurak su yıllarının varlığı, sıklığ1 ve toplam gözlem süresi içerisindeki yüksek oranları havza genelindeki sulak alanlarda gerçekleşmiş negatif yönlü eğilimler ile uyum göstermekte ve söz konusu sav1 desteklemektedir.
Akarçay Kapalı Havzası genliği ve süresi artan hidrolojik kurak dönemler geçirmiştir. Çalışma bulguları ile nümerik olarak ortaya çıkartılan hidrolojik kuraklık, havza genelinde sulak alanlar üzerinde gerçekleşen alansal değişikler ile kendini net bir şekilde göstermektedir. Artan iklim değişikliği baskısı ile sonraki dönemlerde de hidrolojik kuraklığın büyüklüğünün artacağı öngörülmektedir. Bu bağlamda havza su kaynakları yönetimi üzerinde söz sahibi olan aktörlerin geçmişte yaşanan hidrolojik kuraklığı dikkate almaları tavsiye edilmektedir. Çalışma dönemi sonunda süresi artan hidrolojik kurak dönemler ile birlikte artan suya erişim problemi tüm ekosistem üyelerinin ortak sorunudur. Bu kapsamda karar alıcıların havza su kaynaklarının doğal yapısını bozacak faaliyetlerden ivedi olarak uzaklaşması gerektiği düşünülmekte ve önerilmektedir.

Hakem Değerlendirmesi: Dış bağımsız.

Çıkar Çatışması: Yazar çıkar çatışması bildirmemiştir.

Finansal Destek: Yazar bu çalışma için finansal destek almadığını beyan etmiştir.

Peer-review: Externally peer-reviewed.

Conflict of Interest: The author has no conflict of interest to declare.

Grant Support: The author declared that this study has received no financial support.

\section{KAYNAKÇA/REFERENCES}

Abbott, B. W., Bishop, K., Zarnetske, J. P., Minaudo, C., Chapin, F. S., Krause, S., ... Pinay, G. (2019). Human domination of the global water cycle absent from depictions and perceptions. Nature Geoscience, 12(7), 533-540.

Altın, T. B., Sarış, F., \& Altın, B. N. (2020). Determination of drought intensity in Seyhan and Ceyhan River Basins, Turkey, by hydrological drought analysis. Theoretical and Applied Climatology, 139(1), 95107. https://doi.org/10.1007/s00704-019-02957-y

Akbaş, A. (2014). Türkiye üzerindeki önemli kurak ylllar. Coğrafi Bilimler Dergisi, 12(2), 101-118. https://doi.org/10.1501/Cogbil_ 0000000155

Arnell, N. W. (1999). Climate change and global water resources. Global Environmental Change, 9(1), 31-49. https://doi.org/10.1016/ S0959-3780(99)00017-5

Aydın, O., Ünaldı, Ü. E., Duman, N., Çiçek, İ. ve Türkoğlu, N. (2017). Türkiye'de su kitlığının mekânsal ölçekte değerlendirilmesi. Türk Coğrafya Dergisi, 68, 11-18.

Bahadır, M. (2012). Eber ve Akşehir Göllerinin bütünleşik kıyı alanları yönetimi. Coğrafi Bilimler Dergisi, 10(1), 63-90.

Bahadır, M. (2013). Akşehir Gölü'nde alansal değişimlerin uzaktan algilama teknikleri ile belirlenmesi. Marmara Coğrafya Dergisi, 28(1), 246-275.

Bayazıt, M. (1995). Hidroloji. İstanbul: İTÜ İnşaat Fakültesi Matbaası. Bayazıt, M. ve Önöz, B. (2008). Taşkın ve kuraklık hidrolojisi. İstanbul: Nobel Akademik Yayıncilık. 
Bozkurt, D. \& Şen, O. L. (2013). Climate change impacts in the Euphrates-Tigris Basin based on different model and scenario simulations. Journal of Hydrology, 480, 149-161. https://doi. org/10.1016/j.jhydrol.2012.12.021.

Çiçek, İ., \& Duman, N. (2015). Seasonal and annual precipitation trends in Turkey. Carpathian Journal of Earth and Environmental Sciences, 10(2), 77-84.

Dabanli, I. (2018). Drought hazard, vulnerability, and risk assessment in Turkey. Arabian Journal of Geosciences, 11(18), 1-12.

Dore, M. H. (2005). Climate change and changes in global precipitation patterns: what do we know?. Environment International, 31(8), 1167-1181. https://doi.org/10.1016/j.envint.2005 .03.004.

Dönmez, S. (2018). Akşehir Gölü su seviyesinin çekilmesinin meteorolojik ve uydu verileri ile incelenmesi. Gazi Üniversitesi Mühendislik Mimarlık Fakültesi Dergisi, 33(1). 177-188. https:// doi.org/10.17341/gazimmfd.406790.

Erlat, E. \& Türkeş, M. (2013). Observed changes and trends in numbers of summer and tropical days, and the 2010 hot summer in Turkey. International Journal of Climatology, 33(8), 1909-1916. https://doi. org/10.1002/joc.3556.

Esen, F. (2021). Göynük Çayı Havzası'nın (Bingöl) hidroklimatolojik analizi. Firat Üniversitesi SBE Dergisi, 31(1), 25-40.

Fujihara, Y., Tanaka, K., Watanabe, T., Nagano, T. \& Kojiri, T. (2008). Assessing the impacts of climate change on the water resources of the Seyhan River Basin in Turkey: Use of dynamically downscaled data for hydrologic simulations. Journal of Hydrology, 353(1-2), 33-48. doi: 10.1016/j.jhydrol.2008.01.024.

Hirsch, R. M., Slack, J. R. \& Smith, R. A. (1982). Techniques of trend analysis for monthly water quality data. Water Resources Research, 18(1), 107-121.

Huntington, T. G. (2006). Evidence for intensification of the global water cycle: Review and synthesis. Journal of Hydrology, 319(1-4), 83-95. https://doi.org/10.1016/j.jhydrol.2005. 07.003.

Irvem, A., Topaloglu, F. \& Ozfidaner, M. (2012). Trends in Turkish monthly mean streamflow. Journal of Food, Agriculture \& Environment, 10(3-4), 900-904.

Kahya, E. \& Kalayc1, S. (2004). Trend analysis of streamflow in Turkey. Journal of Hydrology, 289(1-4), 128-144. https://doi. org/10.1016/j.jhydrol.2003.11.006.

Kalaycı S. ve Kahya, E. (1998). Susurluk havzası nehirlerinde su kalitesi trendlerinin belirlenmesi. Turkish Journal of Engineering and Environmental Science, 22, 503-514.

Kale, M. M. (2018). Historical shoreline change assessment using DSAS: A case study of Lake Akşehir, SW Turkey. In Current Debates in Sustainable Architecture, Urban Design \& Environmental Studies (pp. 187-196). London: IJOPEC.

Karabulut, M. \& Cosun, F. (2009). Kahramanmaraş ilinde yağışların trend analizi. Coğrafi Bilimler Dergisi, 7(1), 65-83.

Katipoğlu, O. M., Acar, R., \& Şengül, S. (2020). Comparison of meteorological indices for drought monitoring and evaluating: a case study from Euphrates basin, Turkey. Journal of Water and Climate Change, 11(S1), 29-43.
Kisi, O. \& Ay, M. (2014). Comparison of Mann-Kendall and innovative trend method for water quality parameters of the Kizilirmak River, Turkey. Journal of Hydrology, 513, 362-375. https://doi. org/10.1016/j.jhydrol.2014.03.005.

Kolmogorov, A.N. (1933). Sulla determinazone empirica di une legge di distribuzione. G. Ist. Attuari,4(1), 83-91.

Köle, C. ve Gökpınar, F. (2012). Üstel dağılıma uygunluk için bazı uyum iyiliği testlerinin I. tip hata ve güçleri bakımından k1yaslanmaları. Süleyman Demirel Üniversitesi Fen Bilimleri Enstitüsü Dergisi, 16(3), 318-326.

Köle, M. M., Ataol, M. ve Erkal, T. (2016, Ekim). Eber ve Akşehir Gölleri'nde 1990-2016 yilları arasında gerçekleşen alansal değişimler. TÜCAUM Uluslararası Coğrafya Sempozyumu'nda sunulan bildiri, Ankara Üniversitesi, Ankara.

Kuzay, M. ve Tombul, M. (2020). Akarçay Havzası ve Van Gölü Havzası için 1901-2015 Yılları Arasında Standartlaştırılmış Yağış İndeksi'ne (SPI) Göre Trend Analizi. 7(100. Y11 özel say1s1), 51-61.

Lins, H. F. (1985). Streamflow variability in the United States: 19311978. Journal of Climate and Applied Climatology 24, 463-471

Lins, H. F. \& Slack, J. R. (1999). Streamflow trends in the United States. Geophysical Research Letters, 26(2), 227-230.

Loon, A. F. V., Stahl, K., Baldassarre, G. D., Clark, J., Rangecroft, S., Wanders, N., ... \& Van Lanen, H. A. (2016). Drought in a humanmodified world: reframing drought definitions, understanding, and analysis approaches. Hydrology and Earth System Sciences, 20(9), 3631-3650.

Nalbantis, I. (2008). Evaluation of a hydrological drought index. EurWater 23(24), 67-77.

Nalbantis, I. \& Tsakiris, G. (2009). Assessment of hydrological drought revisited. Water Resources Management, 23(5), 881-897.

Oki, T. \& Kanae, S. (2006). Global hydrological cycles and world water resources. Science, 313(5790), 1068-1072.

Önol, B. (2012). Effects of coastal topography on climate: highresolution simulation with a regional climate model. Climate Research, 52, 159-174. https://doi.org/10.3354/cr01077.

Önol, B. \& Semazzi, F. H. M. (2009). Regionalization of climate change simulations over the Eastern Mediterranean. Journal of Climate, 22(8), 1944-1961. https://doi.org/10.1175/2008JCLI1807.1.

Önol, B., Ünal, Y. S. ve Dalfes, H. N. (2009). İklim değişimi senaryosununTürkiye üzerindeki etkilerinin modellenmesi. ITÜ Dergisi/d Mühendislik, 8(5),169-177.

Önöz, B. \& Bayazıt, M. (2003). The Power of Statistical Tests for Trend Detection, Turkish Journal of Engineering \& Environmental Sciences, 27, 247-251.

Özdemir, M. A. ve Bahadır, M. (2011). Eber ve Akşehir göllerinin hidro-klimatik trend analizi. Fiziki Coğrafya Araştırmalar Sistematik ve Bölgesel kitab1 içinde (s. 181-198). İstanbul: Türk Coğrafya Kurumu Yayınları.

Öztürk, M. Z., Çetinkaya, G. ve Aydın, S. (2017). Köppen-Geiger iklim sınıflandırmasına göre Türkiye'nin iklim tipleri. Coğrafya Dergisi, $35,17-27$. 
Shiklomanov, I. A. (1991). The World's water resources. In Proceedings of the international Symposium to Commemorate 25 years of the IHP (pp. 93-126), UNESCO / IHP.

Smirnov, N. (1939). On the estimation of the discrepancy between emprical curves of distribution for two independent samples. Bulletin of Moscow University, 3-16.

Sneyers, R. (1990). On the statistical analysis of series of observations World Meteorological Organization Technical Note 43. World Meteorological Organization: Geneva.

Sönmez, A. Y. \& Kale, S. (2020). Climate change effects on annual streamflow of Filyos River (Turkey). Journal of Water and Climate Change, 11(2), 420-433.

Şen, Ö. L, Ünal, A., Bozkurt, D. \& Kindap T (2011). Temporal changes in the Euphrates and Tigris discharges andteleconnections. Environmental Research Letters, 6(2), https://doi.org/10.1088/17489326/6/2/024012.

Sener, E., Davraz, A. \& Sener, S. (2010). Investigation of Aksehir and Eber Lakes (SW Turkey) coastline change with multitemporal satellite images. Water Resources Management, 24(4), 727-745.

Sönmez, F. K., Koemuescue, A. U., Erkan, A. \& Turgu, E. (2005). An analysis of spatial and temporal dimension of drought vulnerability in Turkey using the standardized precipitation index. Natural Hazards, 35(2), 243-264.

Tağıl, Ş. ve Alevkayalı, Ç. (2014). Eğirdir gölüne kuzeyden dökülen akarsularda akım trendi ve yağış ilişkisi. Balıkesir Üniversitesi Sosyal Bilimler Enstitüsü Dergisi, 17(32), 211-229.

Tekkanat, İ. ve Sarış, F. (2015). Porsuk Çayı Havzasında akarsu akımlarında gözlenen uzun dönemli eğilimler. Türk Coğrafya Dergisi, 64, 69-83.

Tezcan, L., Meriç, B. T., Doğdu, N., Akan, B., Atilla, A. Ö. ve Kurttaş, T. (2002). Akarçay Havzası Hidrojeolojisi ve Yeraltı Suyu Akım Modeli Final Raporu. Hacettepe Üniversitesi Uluslararası Karst Su Kaynaklan Uygulama ve Araştırma Merkezi (ÜKAM) - Devlet Su İşleri (DSİ) Genel Müdürlüğü: Ankara.

Türkeş, M. (1996a). Spatial and temporal analysis of annual rainfall variations in Turkey. International Journal of Climatology, 16(9), 1057-1076.

Türkes, M. (1996b). Meteorological drought in Turkey: A historical perspective 1930-93, Drought Network News. https:// digitalcommons.unl.edu/cgi/viewcontent.cgi? article= 1084\&context=droughtnetnews.
Türkeş, M. (1998). Influence of geopotential heights, cyclone frequency and southern oscillation on rainfall variations in Turkey. International Journal of Climatology, 18(6), 64-680.

Türkeş, M. (2010). Klimatoloji ve meteoroloji (1.bs). İstanbul: Kriter Yayınevi.

Türkeş, M. (2012). Kuraklık, çölleşme ve Birleșmiş Milletler Çölleşme ile Savaşım Sözleşmesi'nin ayrıntılı bir çözümlemesi. Marmara Avrupa Araştırmaları Dergisi, Çevre Özel Sayısı, 20, 7-56.

Türkeş, M. \& Erlat, E. (2003). Precipitation changes and variability in Turkey linked to the North Atlantic Oscillation during the period 1930-2000. International Journal of Climatology, 23(14), 17711796.

Türkeş, M. \& Deniz, Z. A. (2011). Climatology of South Marmara Division (North West Anatolia) and observed variations and trends. Journal of Human Sciences, 8(1), 1579-1600.

Türkeş, M., Koç, T. ve Sarış, F. (2007). Türkiye'nin yağış toplamı ve yoğunluğu dizilerindeki değişikliklerin ve eğilimlerin zamansal ve alansal çözümlenmesi, Coğrafi Bilimler Dergisi, 5(1), 57-73.

Türkeş, M., Sümer, U. M. \& Demir, İ. (2002). Re-evaluation of trends and changes in mean, maximum and minimum temperatures of Turkey for the period 1929-1999, International Journal of Climatology, 22(8), 947-977.

Türkeş, M. \& Tatl1, H. (2011). Use of the spectral clustering to determine coherent precipitation regions in Turkey for the period 1929-2007. International Journal of Climatology, 31(14), 2055-2067.

Toros, H. (2012). Spatio-temporal Precipitation Change Assessments over Turkey. International Journal of Climatology, 32(9),1310 1325.

Trenberth, K. E. (2011). Changes in precipitation with climate change. Climate Research, 47(1-2), 123-138.

Vazifehkhah, S., \& Kahya, E. (2018). Hydrological drought associations with extreme phases of the North Atlantic and Arctic Oscillations over Turkey and northern Iran. International Journal of Climatology, 38(12), 4459-4475.

Yıldırım, Ü., Erdoğan, S. \& Uysal, M. (2011). Changes in the coastline and water level of the Akşehir and Eber Lakes between 1975 and 2009. Water resources management, 25(3), 941-962.

Yu, Y. S., Zou, S., \& Whittemore, D. (1993). Non-parametric trend analysis of water quality data of rivers in Kansas. Journal of Hydrology, 150(1), 61-80. 